Pamiętnik Literacki 2015, 3, s. 195-231

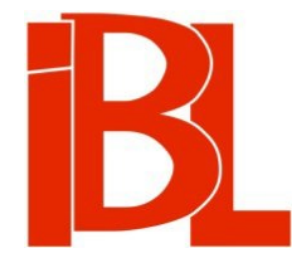

\title{
Listy Jakuba Goldszmita do Elizy \\ Orzeszkowej. Część 1
}

oprac. Bożena Wojnowska 


\title{
2. $\begin{array}{llllllllllllllllll} & \mathrm{M} & \mathrm{A} & \mathrm{T} & \mathrm{E} & \mathrm{R} & \mathrm{I} & \mathrm{A} & \mathrm{E} & \mathrm{Y} & \mathrm{I} & \mathrm{N} & \mathrm{O} & \mathrm{T} & \mathrm{A} & \mathrm{T} & \mathrm{K} & \mathrm{I}\end{array}$
}

Pamiętnik Literacki CVI, 2015, z. 3, PL ISSN 0031-0514

\section{LISTY JAKUBA GOLDSZMITA DO ELIZY ORZESZKOWEJ CZEŚĆ 1}

\author{
Opracowała BOŻENA WOJNOWSKA Instytut Badań Literackich PAN, Warszawa
}

\section{Pożar w Grodnie i nie tylko}

W roku 1862 uczeń VI klasy gimnazjum lubelskiego, 14-letni Jakub Goldszmit, nadesłał do redakcji „Jutrzenki” notkę o pożarze, jaki wybuchł w dzielnicy żydowskiej w Lublinie. Przekazywał wyrazy „wdzięczności i uwielbienia [...] dla współrodaków chrześcijan, którzy $\mathrm{z}$ narażeniem własnego życia ratowali pogorzelców wyznania mojżeszowego". Informował, że w gaszeniu ognia brali również udział koledzy, uczniowie miejscowego gimnazjum (podał nazwisko jednego $z$ nich, Ludwika Budzanowskiego) i zakończył konkluzją: „tak szlachetne objawy współczucia są wynikiem prawdziwej miłości bliźniego" ${ }^{1}$.

Temat pożaru, pogorzelców, wspólnoty poszkodowanych, ofiarności i pomocy potrzebującym będzie powracał w prezentowanych tu listach do Elizy Orzeszkowej. Kim był ich autor?

W „Pamiętniku Literackim” ukazały się niedawno jego listy do Józefa Ignacego Kraszewskiego ${ }^{2}$. W komentarzu do tej publikacji znajdzie czytelnik podstawowe dane o tym prawniku, literacie, dziennikarzu, stryju Janusza Korczaka, zebrane dzięki pionierskiemu studium Marii Falkowskiej o rodzinie pisarza ${ }^{3}$. To, co udało się ustalić dodatkowo (odpowiednie informacje mieszczą się w przypisach do niniejszego artykułu), nie składa się, niestety, na pełniejszą wiedze o tej postaci, pozwalająca objaśnić wszystko, co zawarte w listach. Dotkliwe luki dotyczą zwłaszcza wzmiankowanych szczegółów biografii, głównie jej fazy końcowej, amerykańskiej.

Autor był jednym $z$ wielu żydowskich korespondentów Orzeszkowej, ciążących ku polskości. Znamy ich, chyba w większości, z monumentalnej, nie ukończonej jeszcze edycji jej Listów zebranych, grupującej to, co pisała sama Orzeszkowa ${ }^{4}$.

J. Gold s z m it, list do redakcji, z 16 X 1862. „Jutrzenka” 1862, nr 48, s. 405.

Listy Jakuba Goldszmita do Józefa Ignacego Kraszewskiego. Oprac. B. W o j n o w s k a. „Pamiętnik Literacki” 2013, z. 4.

3 M. Falkows ka, Rodowód Janusza Korczaka. „Biuletyn Żydowskiego Instytutu Historycznego” 1997.

4 E. Or ze s zk ow a, Listy zebrane. T. 1-9. Do druku przygotował i komentarzem opatrzył E. J a nkowski. Wrocław 1954-1981 (t. 10 czeka na wydanie). Dalej do edycji tej odsyłam skrótem O. Ponadto stosuję w artykule skrót W = I. Wiśn i ew ska, Kalendarium życia $i$ twórczości Elizy Orzeszkowej (1841-1910). Maszynopis pracy doktorskiej. IBL PAN. Warszawa 2008. Liczby po skrócie wskazują stronice, jedynie w przypadku Listów zebranych pierwsza liczba, po łączniku, oznacza tom, następne - stronice. Ze skrótów korzystam w artykule wprowadzającym i w komentarzach do listów. 
Część tej korespondencji czeka dotąd na opublikowanie. W tym listy od zasymilowanych Żydów d o autorki Nad Niemnem ${ }^{5}$. Wypowiedzi epistolarne stryja Korczaka należą do tego zespołu. Rodzinne koneksje ich autora oraz związek z listami do Kraszewskiego nadają im szczególne znaczenie. Idąc po tych śladach, zyskuje się szersze spojrzenie na zjawisko integracji w rodzinie Goldszmitów, jego typowość bądź specyficzność dla zbiorowości wykształconych polskich Żydów owego czasu, także możliwość odpowiedzi na pytanie o przebieg tego procesu. $Z$ drugiej strony, zestawienie obu zespołów zachęca, by powrócić do problemu stosunku obojga wybitnych polskich pisarzy do sprawy żydowskiej.

Zatrzymajmy się przy czasopiśmie wspomnianym na początku. Goldszmit nadesłał tam jeszcze jeden list, w którym donosił o datku ojca na budowę nowej synagogi ${ }^{6}$. Czytelnikiem „Jutrzenki”, a także autorem innego listu w tym samym dziale Korespondencje był również brat Jakuba, Józef Goldszmit (ojciec Korczaka ${ }^{7}$ ). To ważny ślad.

O „Jutrzence” pisałam obszerniej we wprowadzeniu do wymienionego opracowania listów w „Pamiętniku Literackim” w r. 2013, zwracając uwagę na powiązania owego organu reformujących się Żydów (1861-1863) z kierowaną przez Kraszewskiego w tym czasie „Gazetą Codzienna/Polska ${ }^{8}$. Tu przypomnę pokrótce główne rysy tego periodyku, zrodzonego $\mathrm{z}$ inspiracji rabina Markusa Jastrowa, kaznodziei „postępowej” synagogi przy ulicy Daniłowiczowskiej. Synagogę tę odwiedzała Orzeszkowa ${ }^{9}$.

Jastrow był promotorem reformowanego judaizmu, zrodzonego w kręgach Ha-

Zbiór ten jest ogromny, liczy ponad 7 tys. pozycji z lat 1878-1910; przechowuje go Archiwum Elizy Orzeszkowej przy Instytucie Badań Literackcih PAN w Warszawie (dalej: AEO), większość pod sygnaturą 800, łamane przez rok napisania listu; nazwiska autorów ułożono alfabetycznie. Sygnaturę tę noszą również listy Goldszmita. Kilkaset pozycji znajduje się w Bibl. Publicznej m. Warszawy (sygn. 2629), niewielka część - w rozproszonych zbiorach.

6 J. Gold s z mit, list do redakcji, z 22 VIII 1863. „Jutrzenka” 1863, nr 39.

7 Józef Gold szmit, list do redakcji, z 10 VI 1863. Jw., nr 25.

$8 \quad$ Zob. Listy Jakuba Goldszmita do Ignacego Kraszewskiego, s. 153, przypis 2.

9 Wiemy o tym bezpośrednio od pisarki. Po latach wspominała te odwiedziny w liście do M. Bl u mb e r g (list z 28 I 1887. AEO, sygn. 287), z którą korespondowała w sprawach tłumaczeń: „bywałam w synagodze (przy ul. Daniłowiczowskiej) i słyszałam parę razy wybornego kaznodzieję, przemawiającego po polsku". Sądziła, że kaznodzieją tym był naczelny rabin Warszawy, Ber Meisels, i że pisze teraz do jego wnuczki. Faktycznie zwracała się do wnuczki Meiselsa, ale ta wyjaśniła, iż to nie jego słuchała wówczas Orzeszkowa, lecz zapewne Markusa Jastrowa, który funkcję kaznodziei tej reformowanej synagogi sprawował w latach 1858-1863 (z przerwami). Pokaźna paczka listów Blumberg do pisarki znajduje się również w AEO (sygn. 378). Prostowali informację tyczącą Meiselsa: J. Detko (Narodowy aspekt kwestii żydowskiej u Elizy Orzeszkowej. „Biuletyn Żydowskiego Instytutu Historycznego" 1961, nr 40, s. 50) i A. C ał a (Asymilacja Żydów w Królestwie Polskim. 〈1864-1897〉. Postawy, konflikty, stereotypy. Warszawa 1989, s. 221, 373). W obydwu publikacjach znajdziemy zacytowany odpowiedni fragment listu, podaje go także M. Ż migrodzk a w monografii Orzeszkowa. Młodość pozytywizmu (Warszawa 1965, s. 53-54). Zob. też G. Borkow ska, Korespondencja Elizy Orzeszkowej z Malwina Blumberg. W zb.: Poetyka, polityka, retoryka. Warszawa 2006, s. 131-142. O Meiselsie zob.: F. K u p fer, Ber Meisels ijego udziat w walkach narodowowyzwoleńczych narodu polskiego. (1846, 1848, 1863-1864). Warszawa 1953. - Meisels Ber. Hasło w: Polski słownik biograficzny. T. 20, z. 2. Kraków 1975. O Jastrowie M. Galas, Rabin Markus Jastrow i jego wizja reformy judaizmu. Studium z dziejów judaizmu $w$ XIX wieku. Kraków 2007 (z tej cennej pozycji niejednokrotnie tu korzystam). 
skali i zachęcał swoje środowisko do szerzenia w języku polskim wiedzy o żydowskim życiu religijnym ${ }^{10}$. Wśród inicjatyw wyrosłych na tym gruncie znajdowała się również „Jutrzenka”. Tytuł tego tygodnika (redagował go Daniel Neufeld) nawiązywał do biblijnej sceny walki Jakuba z Aniołem, trwającej do jutrzenki (Rdz 32, 25-30); miał kojarzyć się ze światłem wiedzy zdolnej wydźwignąć lud żydowski z wielowiekowego poniżenia. Złączenie religii $z$ oświatą oraz postępem podkreślała podobnie metaforyczna apostrofa skierowana do redakcji przez czytelnika, zamieszczona w dziale Korespondencje: „Z pochodnią oświaty w jednym, a księga świętą w drugim ręku, bądź ty prawdy i ludzkości zwiastunką"11.

Te podwójne wektory ideowe, typowe dla integracyjnych dążeń wyrosłych z Haskali, przenikały całe pismo. Prospekt oznajmiał, że periodyk będzie zachowawczy w sprawach religijnych, postępowy zaś - w społecznych.

Dział, który pomieścił teksty obu Goldszmitów, ciekawie redagowany, powtarzający się w każdym numerze, zbliżał tygodnik do prawdziwego forum wymiany myśli. Redaktorowi zależało, by nawiązać z czytelnikami jak najszerszą współpracę (oczywiście nie wszystkie listy pochodziły faktycznie od nich). W podpisach widniały nierzadko nazwiska polskie, i to również pod tekstami popierającymi linię periodyku. Dla przykładu - Bartłomiej Prostak dyskutując z Joskiem Mielnickim o prawach obywatelskich ludności żydowskiej przeczył wyrażanej przezeń opinii (zadomowionej od oświecenia, a niezgodnej z jego liberalnymi założeniami), stwierdzającej, że aby je uzyskać, trzeba na nie zasłużyć. Zdanie przeciwne, dowodzące, iż jako prawo naturalne przysługują one każdej ludzkiej istocie $z$ racji urodzenia, brzmiało - jako wygłoszone przez „polskiego” czytelnika - szczególnie mocno ${ }^{12}$.

Podobną strategią odznaczały się przeglądy aktualnych wydarzeń. W osobnych rubrykach przedstawiano fakty mające wykazać, że integracja jest nie tylko konieczna, ale i możliwa. Donoszono obficie o świadczeniu sobie wzajemnej pomocy przez Żydów i chrześcijan - notka Jakuba Goldszmita była jedną z wielu. Wyróżniała się opowiastka, przytoczona za ludowym pismem „Kmiotek”, której treść,

„Jutrzenka” 1861, nr 1. Pismo zaczęło wychodzić 5 VII tego roku. Prospekt był osobnym drukiem. Przechowuje go Bibl. Uniwersytecka w Warszawie, jest on dołączony do kompletu wszystkich trzech roczników tygodnika (obecnie zdigitalizowanych). W bibliograficznej notce o publikacji Modlitwy dla Polek wyznania mojżeszowego (nr 2, s. 5) adnotacja: „Książeczka ta opatrzona aprobatą Dra Jastrowa [...]".

Zob. B. Pro stak, list do redakcji, z 26 X 1861. „Jutrzenka” 1861, nr 23. Pismo niejednokrotnie wracało jeszcze do tej sprawy, fundamentalnej dla prawnego położenia Żydów w Polsce: „zgodna z duchem wieku jest równość wszystkich wobec prawa i równość ich obowiązków. Wprowadzeniu [...] zasady tej w wykonanie współrodacy nasi, jakiegobądź wyznania, natchnieni miłością ewangeliczną niewątpliwie przyklasną” (H. G la t t s t e r n, Rzut oka na redakcję „Jutrzenki”. Jw., 1862, nr 1, s. 12); „Jak słabo się zarysowuje u nas wyobrażenie o stosunku praw człowieka do jego obowiązków, dowodzi [...], że kilku światłych [...] mężów [...] dało do zrozumienia, że [...] należałoby frymarczyć naszym równouprawnieniem, obwarunkowując je poprzednim obowiązków obywatelskich poczuciem i wypełnieniem. Co za kolosalna nielogiczność! Żądać od człowieka, by z gó ry zapłacił za święte $z$ natury swej, nietykalne prawa [...]. Człowiek przychodzi na świat $z$ dyplomem na obywatela i już w kołysce nim jest; obowiązki spadają na jego barki po dojściu do pełnoletniości jako skutek praw, nigdy zaś jako ich przyczyna [...]" (S. Trachtenberg, Wariacje na oklepany temat. Jw., nr 10, s. 3, przypis). 
zbieżna z tamtą notką, funkcjonowała w „Jutrzence” nieomal jako emblemat postulowanych wzorców współżycia. Mówiła o pożarze w żydowskim domu i ofiarnym ratowaniu żydowskiego dziecka przez chrześcijańskiego sąsiada. Przysługa była wzajemna - po latach Chaim wydobył rodzinę Marcina z nędzy. Rzecz kończyła się słowami żony Marcina: „Wszyscyśmy dzieci jednego Boga i bliźni, chociaż się inaczej modlimy do Niego”. Redakcja poprzedziła streszczenie krótkim wstępem: „Wszelka idea zrodzona w szczupłym kole wybranych wtedy dopiero w czyn przechodzi, kiedy przenika wszystkie warstwy społeczne i zapuszcza korzenie w serca ludu" ${ }^{13}$.

W roku 1885 wybuchł w Grodnie pożar. Jakub Goldszmit zamieścił w liście wyrazy współczucia (pisarka straciła w katastrofie znaczną część księgozbioru). Uczynił to zaraz po tym, gdy inny pożar - w Sandomierzu - zniszczył domy ludności żydowskiej. Prosił o pozwolenie wygłoszenia tam odczytu na rzecz żydowskich pogorzelców (tj. streszczenia rozprawy $O$ Żydach $i$ kwestii żydowskiej).

Orzeszkowa była wstrzaśnięta nieszczęściem, które spotkało miasto. Do licznych form pomocy, w jaką się włączyła, należał cykl reportaży noszący tytuł $Z$ pożogi, ogłoszony z myślą o pobudzeniu czytelników do ofiarności (ukazał się najpierw w „Kraju”, później w wydaniu osobnym). Jeden z tekstów poświęciła osobie majstra murarskiego, Jana Czerniawskiego, szczególnie aktywnego w gaszeniu pożaru; o jego heroizmie wspominała później w listach. Nie szczędziła mu słów uznania: „O, nieznany i maluczki! iluż wielkich tego świata pozazdrościć by mogło wielkości twej duszy". Dowiadujemy się, że zorganizował ratowanie biblioteki Orzeszkowej, z narażeniem życia spieszył, by ocalić cudzy dobytek, walczył z ogniem grożącym kościołowi, pytany zaś o zdrowie po wypadku, jakiego doznał, niepokoił się: „Cóż tam... dzieje się... z tymi biednymi ludźmi?" 14

O zachowaniach samej pisarki czytamy w tymże „Kraju”:

Godna jest podziwienia, bo przenosi $z$ uśmiechem klęskę materialną, co ją spotkała, i zajętą jest wyłącznie losem swych współobywateli [...]. Myśli tylko o innych i niechętnie mówi o swoich stratach, kiedy ją zapytują, spieszy znów skierować rozmowę do nieszczęśliwego losu innych ${ }^{15}$.

Podobne poznaje się podobnym! Orzeszkowa umiała odkryć u „maluczkich”

13 Przeglad pism krajowych. „Jutrzenka” 1862, nr 21. Opowiastka o tytule Chrześcijanin i Żyd ukazała się w „Kmiotku” (1862, nry 12-13); w tymże roczniku i poprzednim drukowano regularnie Opowiadania z „Pisma Św.” [„Starego Testamentu”]. Periodykiem kierował wtedy Jan Kanty Gregorowicz (pseud. Janek z Bielca), Orzeszkowa korespondowała z nim serdecznie m.in. w sprawach żydowskich. Dzięki jego staraniom Kraszewski redagował wspominaną tu wielokrotnie „Gazetę Codzienną/Polską". Jakub Goldszmit wymienił Gregorowicza jako sumiennego biografa bohatera swego szkicu, Szymela Jankielowicza Kaftana („Izraelita” 1867, nr 23).

14 E. Or ze s z k ow a, $Z$ pożogi. W: Drobiazgi. Warszawa 1892, s. 25. Tanie zbiorowe wydanie dziet. T. 39. Rzeczone teksty (pod pierwotnym tytułem Wspomnienia) ukazały się w „Kraju” w roku 1885. Oprócz reportażu pisarka nadesłała do „Kraju” (1885, nr 28) osobną korespondencję o J. Czerniawskim, wzywającą do składek na jego rzecz. Wzmianki o nim w listach do redaktora czasopisma, Erazma Piltza (O-1). Obszerniej o tym pożarze i akcjach pomocy, w jakich Orzeszkowa wzięła udział - W 670-701. Nie był to jedyny pożar w Grodnie. W Przegladzie pism krajowych („Jutrzenka” 1862, nr 18) znajdziemy materiał przedrukowany z „Gazety Codziennej/Polskiej” o zbieraniu składek w kościołach Grodna „dla nieszczęśliwych pogorzelców żydowskich tamecznych”. Autor dodał w następnych numerach informację o rewanżu: „w nagrodę tego współwyznawcy nasi przyłożyli się w Krakowie do odbudowania kościoła" (jw., nry 89-90). 
nieprzeciętne przymioty moralne i wrażliwość, bo sama była osobowością o wielkiej wrażliwości moralnej. Ta jej cecha, długi czas ukryta pod maska trzeźwości intelektualnej, kultu wiedzy i rozumu, dawała o sobie znać już u zarania twórczości. Stanowiła trwały rys jej portretu pisarskiego.

Obrazy pożarów w „Jutrzence” i postawę autorki Z pożogi dzieli przeszło 20 lat. Mimo to można próbować zestawić obydwa podejścia. Przerzucić łuk nad czasem i zapytać uczestników wyobrażonego dialogu: czy gdy wybucha pożar, ważniejsza jest oświata, czy moralność? Co odgrywa większą rolę, kiedy drugiemu zagraża niebezpieczeństwo (lub bieda): właściwe umiejętności czy moralne walory poświęcenia i dobre serce? Problem stosunku nauki i miłosierdzia wolno uznać - z zastrzeżeniami - za wspólny obu stronom. $Z$ zastrzeżeniami, bo pojęcia były nieostre. W jednym i drugim przypadku język moralności religijnej przełamywał się z terminami wziętymi z obszaru etyki świeckiej. W retoryce „Jutrzenki” dominowała chęć pogodzenia idei macierzystej z kategoriami typowymi dla ideologii oświeceniowej. W publicystyce Orzeszkowej „miłość bliźniego” przybierała nierzadko formę „braterstwa”, pojawiały się też treści związane z humanistyczna norma altruizmu, przejętą od filozoficznych patronów epoki.

Dla przykładu - w autorskiej definicji miłosierdzia (znajdziemy ją w osobnej rozprawie Orzeszkowej) słychać wyraźnie echo religijnych wskazań moralnych: „Miłosierdzie - wyraz to zbiorowy. Mieszczą się w nim pojęcia uczuć i cnót wielu: litości, dobroczynności, poświęcenia, przebaczenia”. Padające zaś dalej (w tej samej rozprawie) określenie „oświecona miłość bliźniego” to z kolei dobry przykład owego węzła, w jaki zaplatały się u pisarki moralne pojęcia judeochrześcijańskie $z$ demokratycznymi ideami oświecenia i moralistyką altruizmu ${ }^{16}$.

W obozie integracjonistów zestrojenie „miłości bliźniego” z ideałami równości i z humanitaryzmem dokonywało się na różne sposoby. Podkreślano np., że przykazanie to można też przełożyć: „Kochaj bliźniego, bo jest równy tobie”. Tłumaczono, iż „bliźni” to „każdy”, nie tylko współwyznawca. Utożsamiano czyn miłosierdzia, dobroczynność, $z$ czynem ludzkości ${ }^{17}$. Wprawdzie to ostatnie pojęcie miało nieco

16 E. Orzes z kow a, O wpływie nauki na rozwój miłosierdzia. Lwów 1876 (odczyt wygłoszony w Warszawie na rzecz Towarzystwa Osad Rolnych i Przytułków Rzemieślniczych w r. 1875). Cyt. z: Publicystyka społeczna. T. 1. Wybór, wstęp G. B ork ow s ka. Oprac. edytorskie I. W iś n i ew s ka. Kraków 2005, s. 116, 123. Inne przykłady owej synkretycznej retoryki: w prośbie do rodziny Silbersteinów o wspomożenie grodzieńskiej Kasy Ubogich - zwrot „w imię powszechnego ludzkiego braterstwa” w liście E. Or z e s z k ow ej do T. Silberstein (z 27 IX 1896. O-7 303); „Nie filosemityzm przemawia w tej chwili do mego umysłu i serca, lecz ludzkość, chrześcijańska litość i polska cywilizacja” - zdanie w liście do J. Gadomskiego (z maja 1903. O-8 363), napisane po pogromie w Kiszyniowie.

17 Zob. C. i Z. J., Miłość bratnia. „Jutrzenka” 1861, nr 12. - [D. Ne u feld], Synaj. Jw., nr 21. J. L. D. Wi e n e r, Objaśnienie kilku zasad uniwersalnie religijnych. Jw., 1862, nry 2, 16. - [I. K r a m s z ty k], Mowa miana przy otwarciu ochronki przy Domu Przytułku w r. 1863. „Kalendarz dla Izraelitów na Rok od Stworzenia Świata 5631 [...] 1870” (tu m.in. zob. słowa: „witam go [tj. przytułek] jako świeżą, na ołtarzu ludzkości zaniesioną, a Bogu najmilszą ofiarę”, jako „czyn miłosierdzia, czyn ludzkości, czyn szlachetnej duszy przynoszący ulgę zbolałemu sercu, zmniejszający cierpienia [...]”, s. 79). O możliwych tłumaczeniach przykazania miłości w tradycji żydowskiej-zob. A. La c o c qu e, P. Ri c o e u r, Myśleć biblijnie. Przeł. E. Muk oi d, M. Ta rnow s ka. Kraków 2003, s. 127 („będziesz go [tj. bliźniego] miłował, ponieważ jest człowiekiem, jak ty sam”; 
inny sens u publicystów „Jutrzenki”, a inny u Orzeszkowej, ale niuanse były nieuchwytne na powierzchni tekstów. W obu ich grupach daje się odczytać owo zbliżanie dawnych i nowych idei, u Orzeszkowej - bardziej może nieświadome, u publicystów „Jutrzenki” zaś jawne i programowe.

Wróćmy do pytania o paralelę obu stanowisk. „Jutrzenka” roztrząsała kwestię od strony relacji między oświatą świecką a religią. Orzeszkowa badała różne formy miłosierdzia, bliskie „miłości bliźniego”, i odnosiła je do korzyści, jakie daje wiedza. We wzmiankowanej rozprawie $O$ wpływie nauki na rozwój miłosierdzia pisarka rozważała oba pojęcia tytułowe na tle stosunku rozumu i uczucia w postępowaniu. Nie zastanawiała się głębiej nad genezą analizowanej idei etycznej, nie docierała do jej podstaw światopoglądowych, religijnych bądź świeckich. W każdym razie nie wprost. Pytanie, które sformułowałam wcześniej, uznałaby zapewne za niewłaściwe. Uważała, że i rozum, i uczucia wydaja się ważne, nakazy sumienia i rozsądek są równorzędne i współzależne. Oświata wspiera moralność, odpowiednio ukierunkowuje wypływające $z$ niej postępki, niesienie pomocy zaś okazuje się skuteczne, kiedy człowiek uprzytamnia sobie, co i jak trzeba czynić. Podobnie przekonywano w „Jutrzence”, kiedy zaklinano, że oświata nie sprzeciwia się religii. A jednak wiedza o tym, jak gasić pożary, nie miała większego znaczenia w reportażach $Z$ pożogi ani w historyjkach relacjonowanych w tygodniku Neufelda. Istotna była opowieść o pełnych bezinteresownego oddania czynach „maluczkich” (niekiedy nawet analfabetów).

Sprawom dobroczynności szeroko rozumianym „Jutrzenka” poświęcała wiele uwagi. Podobnie jak później „Izraelita”, pismo, z którym Orzeszkowa utrzymywała bezpośrednie kontakty. Na łamach obu tygodników obficie notowano przejawy indywidualnej ofiarności wśród współwyznawców, informowano o charytatywnej działalności odpowiednich wydziałów gminy żydowskiej oraz innych instytucji powołanych do świadczenia zorganizowanej pomocy, jak ochrony, szpitale, podawano wiadomości o dobroczynnych funduszach prywatnych, także o stowarzyszeniach samopomocowych, niejednokrotnie wówczas mieszanych, chrześcijańsko-żydowskich. W podtekście istotny był zamiar propagandowy: chęć przeciwstawienia się stereotypom materializmu i chciwości żydowskiej, tak uporczywym w powszechnej świadomości, że groziło to przylgnięciem owych cech narzuconej tożsamości i do żydowskich odbiorców. Należało zatem przeciwdziałać temu. A polska publiczność przekonać, iż etyka judaizmu prowadzi do podobnych zachowań, co dobroczynność w świecie chrześcijańskim.

W propagowaniu dobroczynności uciekano się też do twierdzeń teologicznych. Racji dostarczała idea Przymierza. Dowodzono, że obraz Boga pełnego gniewu i mściwości nie jest jedyny ani dominujący w tradycji żydowskiej. Równolegle uobecnia się wizerunek Boga miłosiernego, zatroskanego o całą ludzkość: uniwersalna figura Opatrzności, która służyła - i nadal służy - za wzór czynom „miłości miłosiernej”, opiekowania się obcymi, dziełom ofiarności, poświęcenia, przebaczenia ${ }^{18}$. Ułatwiało to odnalezienie się również w kulturze zsekularyzowanej, gdzie

„kochaj bliźniego swego, bo on jest jak ty”; „bo jest równy tobie”). Warto tu wspomnieć, że motto: „Miłuj bliźniego jak siebie samego”, miało być częścią godła Warszawskiej Szkoły Rabinów według niezrealizowanego projektu A. Sterna (1818). 
wymienione działania, włączone w świecką konstelację ideową, cenione były pod nazwą „filantropia”. Granice były jednak płynne - nie dawało się jasno oddzielić miłości do Boga od miłości do człowieka w opisach zachowań, których fundament pozostawał ostatecznie niedookreślony ${ }^{19}$.

„Jutrzenka” etykę Dekalogu próbowała zastosować także do moralności publicznej. Podobnie jak Kraszewski, który podkreślał, że jej zasady winny być fundamentem wzajemnych stosunków między Polakami a Żydami. Pisarz wskazywał przy tym otwarcie na chrześcijańskie inspiracje owej idei. Orzeszkowa, owszem, w wielu miejscach wyrażała się o chrześcijaństwie $z$ uznaniem, lecz nie wyznawczo. We wczesnych tekstach chwaliła chrześcijaństwo za szerzenie idei równości, miłości, przebaczenia, potwierdzała pozytywną rolę tej religii w rozwoju europejskiej cywilizacji (np. w artykule $O$ postępie ${ }^{20}$ ), ale szukała wtedy - i znajdowała - innych patronów swojej refleksji filantropijnej i społecznej.

W szkicu dla „Kalendarza dla Izraelitów”, poprzedzającym fundamentalną rozprawę O Żydach i kwestii żydowskiej (1882) napisała:

Jedną z idei, coraz częściej i silniej odzywających się w myśli, sumieniu i mowie narodu naszego, jest zlanie się dwu ludności ziemię naszą zamieszkujących: chrześcijańskiej i niechrześcijańskiej, w całość zgodną i spójną; zlanie się takie, któremu by za szerokie i mocne podstawy służyły zdrowe pojęcia o wspólnym interesie, zarówno jak sprawiedliwe i życzliwe uczucia ${ }^{21}$.

Podane tu powody dążenia do dobrych stosunków między obu nacjami sa z różnych terenów ideowych. To zasady etyki utylitarnej, odwołujące się do rozsądnej kalkulacji: daję, ile odbieram, oraz te, wywodzące się ze sfery nastawień i uczuć

(Kazanie miane [...] $w$ Synagodze Daniłowiczowskiej). Jw., 1867, nr 6: „Nasz Bóg jest miłosierny i stąd też przykazanie o miłości bliźniego, stąd tyle dobroczynności i miłosierdzia w naszym życiu religijnym" (o Cylkowie zob. monografię: Izaak Cylkow 〈1841-1908〉. Życie idzieło. Red. M. G a la s. Budapeszt-Kraków 2010; Cylkowa przekład Biblii 〈z hebrajskiego na polski〉 wysoko cenił Cz. Miłosz, zwłaszcza tłumaczenia psalmów, które niekiedy dostarczały mu wzorów 〈Cylkow był pierwszym kaznodzieją Wielkiej Synagogi na Tłomackiem, od r. 1873〉). - B. B i r e n c w e i g, Rozbiór niektórych zarzutów odnoszacych się do Izraelitów i ich wiary. „Izraelita” 1867, nr 7 (autor powołuje się na czołowych przedstawicieli judaizmu haskalowego z M. Mendelsonem na czele oraz na opinie T. Czackiego, J. Lelewela). - Przyszłość Żydów. Jw., 1875, nr 20.

19 Zob. E. Mazu r, Dobroczynność $w$ Warszawie XIX wieku. Warszawa 1999. Na temat przejścia od chrześcijańskich idei i praktyk miłosierdzia do świeckiej filantropii - zob. B. Ge re mek, Litość i szubienica. Dzieje nędzy i miłosierdzia. Warszawa 1989. Przy całej nieokreśloności pojęcia uznawano wówczas filantropię za jedną $\mathrm{z}$ form pracy u podstaw (mając na myśli wielorakie działania oświatowe i charytatywne). Intensywną aktywność w tym kierunku rozwijali również masoni, dobroczynność zaliczała się np. do podstawowych zadań wolnomularskiej loży w Grodnie, której członkowie założyli pierwsze w tym mieście (grudzień 1820) Towarzystwo Dobroczynności. Do loży tej, o nazwie Przyjaciele Ludzkości, należał ojciec Orzeszkowej, Benedykt Pawłowski. O nakładaniu się idei filantropijnych i ewangelicznego miłosierdzia w czasach postyczniowych - zob. B. K. Obs u l e w i c z, Eliza Orzeszkowa i Bolesław Prus o filantropii. W zb.: Etyka i literatura. Pisarze polscy lat 1863-1918 w poszukiwaniu wzorców życia i sztuki. Red. E. I hnatowicz, E. Paczoska. Warszawa 2006.

20 E. Orzeszkowa, O postępie. „Tygodnik Mód i Powieści” 1874, nry 20-24. Przedruk w: Publicystyka społeczna. Na podstawie tego artykułu autorka wygłosiła w czasie kuracji w Nowym Mieście nad Pilica, w r. 1876, odczyt o postępie (ibidem, s. 73).

21 E. Orzeszkow a, Stowo wstępne. „Kalendarz dla Izraelitów na Rok 5642 [...] 1881/82”, s. 25. Cyt. z: Publicystyka społeczna, s. 342. 
zbliżonych do bezinteresownej „miłości bliźniego”. U Orzeszkowej te dwa rodzaje motywacji współistniały ze sobą, przeplatały się i z trudem dają się rozdzielić. Pierwsza linia, mocno tkwiąca w cywilizacyjnym programie pozytywistów, dominowała w publicystyce. Druga, zakorzeniona w etycznej wrażliwości pisarki, najdobitniej przejawiała się w prozie. Jaką treść miało to drugie podejście?

Cofnijmy się do odwiedzin pisarki w synagodze przy ul. Daniłowiczowskiej. Jastrow, jej ówczesny kaznodzieja, włączył się, jak inni warszawscy rabini (Ber Meisels, Izaak Kramsztyk) w czynne popieranie przedpowstaniowych manifestacji patriotycznych. Brała w nich również udział ludność żydowska. Moment był podniosły. Prasa ówczesna, chwilowo wolna od cenzury, a także późniejsza historiografia, pisały o rewolucji moralnej, przebudzeniu narodowym, zbrataniu polsko-żydowskim. W swoich kazaniach Jastrow mówił wtedy wprost o włączeniu norm etycznych we wzajemne stosunki, podkreślał z satysfakcją, że zapanowały zgoda i miłość między obu nacjami. Triumf tych wartości uznał za dzieło Opatrzności, znak bezpośredniej ingerencji Stwórcy w dzieje ${ }^{22}$.

Orzeszkowa słuchała tych kazań razem z innymi uczestnikami wydarzeń. Polacy przychodzili wtedy tłumnie do synagog, gdzie odprawiano specjalne nabożeństwa w intencji manifestantów, szukali tam solidarności, wyrazów pokrzepienia i otuchy. W mowach Jastrowa odnajdywali znajome, mile brzmiące dla ucha wątki prowidencjalizmu romantycznego: rządy Opatrzności gwarantowały lepszą przy-

Zob. G a la s, op. cit., zwłaszcza podrozdz. Jastrow kaznodzieja oraz Stosunki żydowsko-polskie $i$ idee reformy $w$ kazaniach polskich. Według autora idea zbratania i jedności losów polskich i żydowskich była przedmiotem prawie wszystkich wystapień Jastrowa w Warszawie. Kaznodzieja wymieniał Mickiewicza, obok Lelewela, Słowackiego, Krasińskiego, jako jednego z głównych patronów moralnego odrodzenia kraju. Warto tu może przytoczyć obszerniejszy fragment takiego wystapienia: „Bóg jest sprawiedliwym Sędzią świata, i jak On kraj ten, w którym mieszkamy od wieków [...], w niedościgłej swej poniżył mądrości przez rozdział i rozdwojenie, [...] tak On znowu kraj nasz podniesie, gdyśmy dali tak świetny i wiecznie pamiętny dowód powrotu do Boga i nakazanej przezeń miłości bliźniego, gdy kraj nasz [...] całemu pokazał światu rzadki w historii przykład zjednoczenia i zbratania wszystkich jego synów, świetnego pogodzenia wszystkich rozdzielonych dotąd jednej matki dzieci” (jw., s. 114). Według Galasa zbiór kazań Jastrowa zawiera 8 kazań, inne zaginęły lub skonfiskowano je po uwięzieniu rabina w Cytadeli. W publikacji K u p fe r a (op. cit., s. 142) znajdujemy takie oto fragmenty tekstu Jastrowa, napisanego po śmierci Meiselsa (tłumaczonego przez Kupfera z niemieckiego): „Zbratanie zrodziło się z Opatrzności Bożej, która często obroniła już Żydów przed groźbą zguby”, „Wraz ze mną przyszło mu [tj. Meiselsowi] opuścić miejsce, gdzie miłość i jedność były świętym celem, do którego zmierzał, i gdzie miłość i jedność są wspaniałą pamiątką, którą po sobie zostawił”. Kazania Kramsztyka miały więcej szczęścia, zostały zebrane po jego śmierci i opublikowane w Krakowie w 1892 roku. Słynna jego mowa na pogrzebie pięciu poległych w r. 1861 ukazała się w tym samym roku w krakowskim „Czasie”. Zob. prace na temat Kramsztyka: A. W e in, Kramsztyk Izaak. Hasło w: Polski słownik biograficzny. T. 15. Wrocław 1970. - H. Kr o s z c z or, Reformator i kaznodzieja. (Izaak Kramsztyk). W: Kartki z historii Żydów $w$ Warszawie $w$ XIX-XX w. Sylwetki, szkice. Warszawa 1979. O Meiselsie, Jastrowie, Kramsztyku i „zbrataniu polsko-żydowskim” zob. też A. Jagodzińska, Pomiędzy. Akulturacja Żydów Warszawy $w$ drugiej połowie XIX wieku. Wrocław 2008, s. 44-58. Trzeba tu przypomnieć, że owo polityczne pojednanie miało miejsce tuż po tzw. wojnie polsko-żydowskiej, która toczyła się na łamach ówczesnej prasy i choć wiązała się $\mathrm{z}$ błahym w gruncie rzeczy incydentem, ujawniła nagromadzone pokłady niechęci i wzgardy zwłaszcza wobec wzbogaconych Żydów (zob. K. Bartos z e w i c z, Wojna żydowska w roku 1859. 〈Poczatki asymilacji i antysemityzmu〉. Warszawa 1913). Publicyści „Jutrzenki” oraz „Izraelity” czerpali wiele z kazań Jastrowa i Kramsztyka. 
szłość narodu, niosły nadzieję zwycięstwa, zachęcały do współpracy przy budowie dobrych relacji już teraz. Listowne sprawozdanie pisarki z tych odwiedzin dowodzi, że słowa skłaniające do przeniesienia bliskich jej pojęć moralnych w sferę dziejową i społeczną wywarły na niej wielkie wrażenie: „Jego postać i jego mowy utkwiły mi w pamięci" ${ }^{23}$. Obydwa nakazy - zgody i miłości, które kaznodzieja głosił z taka energia, wielokrotnie potem wracały w dyskursie Orzeszkowej o stosunkach między narodami i warstwami społecznymi. Stworzyły podstawę pożądanych relacji z narodem żydowskim ${ }^{24}$.

Na jaki grunt padały owe idee? Wśród różnorodnych opinii w tej kwestii wyróżniają się te, które wiążą wyjątkowe stanowisko pisarki z jej pełnymi pasji wyobrażeniami o analogii polskich i żydowskich losów historycznych ${ }^{25}$. Sama Orzeszkowa tak przedstawiała ten splot (w liście do Samuela Peltyna, redaktora „Izraelity”):

Miałam zawsze dla Izraelitów współczucie i pewną sympatię, wzmożoną jeszcze tym, że w losie ich niezmierne widzę podobieństwo do losów naszego narodu i z boleścią przypuszczam, że przyszłe obu społeczeństw przeznaczenia mogą się ściślej zbratać wspólną dolą nieszczęścia, tułactwa i poniżenia ${ }^{26}$.

Motyw ten - wspólnoty cierpienia, występujący nie tylko u autorki Nad Niemnem ${ }^{27}$, zdaje się naprowadzać na ważną strunę jej wrażliwości, związaną z do-

Or ze s z k ow a, list do Blumberg. Tu jeszcze słowa: „Były to piękne czasy dążenia do powszechnej równości i zgody, w których młodziutkie moje serce namiętny brało udział i z których może pierwsze upadło w nie ziarno miłości dla wszystkich bez wyjątku mieszkańców kraju naszego". Zob. np. E. Orzeszkowa, list do F. Rawity Gawrońskiego, z 1 IX 1884. O-3 130: „Wszelkie antysemityzmy, antyrusinizmy itd. są naprzód rzeczą głupią i złą, następnie dla nas zabójczą. Poznawać się, aby się łączyć, aby wspólnie iść ku dobrym i pożądanym celom, przebaczyć przeszłość, razem pracować dla przyszłości - jakież cudowne marzenie!” Pisarka wyjawiła tu uczucia żywione od młodości. Pod koniec życia (1905) E. Orze s z k ow a w Liście otwartym do społeczeństwa rosyjskiego (w: Publicystyka społeczna) poświadczyła uniwersalność wyznawanych wartości. Czy wielowiekowego sporu Polski i Rosji nie można by zakończyć? - zapytywała - „na podstawach sprawiedliwości i wzajemnej zgody?”, „uczuć poszanowania, ufności i sympatii”, „pod sztandarem niosącym hasło: wzajemna ufność, wzajemne poszanowanie osobnikowych praw narodów! [...] polityka [...] wielka nie w sensie Macchiawelów lub Neronów, lecz w sensie - Chrystusa” (ibidem, s. 302). O kulturowym znaczeniu religijnej idei przebaczenia zob. H. A r e n d t, Kondycja ludzka. Przeł. A. Ła g odzka. Warszawa 2000, podrozdz. Nieodwracalność i władza przebaczania.

Zob. G. Borkowska, Żydzi Orzeszkowej. W zb.: Kwestia żydowska w XIX wieku. Spory o tożsamość Polaków. Red. G. B or k ow s k a, M. Ru d kow s k a. Warszawa 2004, s. 139-150. E. Orzeszkowa, list do S. Peltyna, z 12 VIII 1870. AEO, sygn. 333. Listy Orzeszkowej do Peltyna drukowano we fragmentach w „Izraelicie”. Obszerne z nich wyjątki podaje I. B u tki ew ic zówna w książce Powieści i nowele żydowskie Elizy Orzeszkowej (Lublin 1937, s. 1-8), dwa fragmenty też cytuje C ała (op. cit., s. 222, 224). Oryginały przechowywało Towarzystwo im. Elizy Orzeszkowej w Warszawie, gdzie znalazły się dzięki darowi córki Peltynów, M. Nowakowej (1936). Po burzliwej wojennej historii zbiorów Towarzystwa przejęło je Archiwum (łącznie z resztą ocalałych materiałów). Jest tych listów cztery z lat 1870-1871 oraz jeden z 1888 r. (ten ostatni wraz z kopią maszynopisowa). Z listów Peltyna do Orzeszkowej zachował się jeden (z 1885 r.). Publikację tej korespondencji przewiduje się w tomie 11 Listów zebranych.

27 O istnieniu tego wątku w polskiej literaturze zob. A. F abia n ow s ki, Judaizm, diaspora, mesjanizm. Romantyczne myślenie analogiami. W zb.: Kwestia żydowska w XIX wieku. Jako ciekawostkę chciałoby się tu dopisać fragment rozmowy cadyka Maggida Izraela z księciem Adamem Czartoryskim (Kozienice 1805), podany przez M. Bubera (Gog i Magog. Kronika chasydzka. Przeł., wstęp J. Garewi cz. Warszawa 1999, s. 151): „Nas Bóg przed wiekami rozproszył po ziemi [...] 
świadczeniem powstania styczniowego. Jak wiemy, brała w nim udział - okazywała czynna pomoc powstańcom na Polesiu, potajemnie przewiozła Romualda Traugutta do Królestwa. Dramat rozbudzonych nadziei i wielkiej klęski, jakim była przegrana powstania, wyrył w umysłowości pisarki głęboki ślad. Znaczył nie tylko w chronologicznym porządku biografii - jako coś, co kiedyś było i nie wróci. Wywołane doznania trwały w czasie wewnętrznym, miały wpływ na cała egzystencję, odcisnęły piętno na sposobie przeżywania świata. Nie zawsze ujawniało się to na zewnątrz: w twórczości - co oczywiste - z powodów cenzuralnych. Orzeszkowa sama też mogła spychać w głąb to źródłowe doświadczenie, ulegając - bardziej lub mniej bezwiednie - pozytywistycznym normom. Albo po prostu tamowała owe wspomnienia jako nazbyt dla siebie traumatyczne ${ }^{28}$.

Tu zapewne leży przyczyna tego, co zauważyła Grażyna Borkowska: pisarka szerzej nie rozwinęła wskazanego motywu w twórczości beletrystycznej (podobnie jak motywu powstania). Można go jednak wytropić. Choćby przez zestawienie struktury Meira Ezofowicza z fabuła Nad Niemnem, o czym jeszcze wspomnę.

„Nieszczęście, tułactwo, poniżenie” ${ }^{29}$ - te wymienione w liście do Peltyna konsekwencje historycznej przegranej nie sprowadzały się w ujęciu pisarki do zranionej dumy narodowej. Godziły nie tyle w uczucia, ile w sferę wartości: w prawo do decydowania o sobie, spełnienia wyznaczonej misji. Orzeszkowa w korespondencji z Peltynem wyraziła to następująco:

Stworzyłam sobie takie wyobrażenie, że każdy naród posiada udzielone sobie wyższą siłą i mądrością pewne wyłączne posłannictwo, w imię którego żyje, działa i cierpi. Być może, iż każdemu narodowi przeznaczonym jest, aby dopisał jedną zgłoskę w tym wielkim wyrazie, który jest wyrazem bezwiednych dążeń całej ludzkości. Zgłoską naznaczoną ludowi polskiemu jest wolność, izraelskiemu - wiara w Jedynego Boga. Obie idee wielkie, do wcielenia tak trudne, że narody, które je w życie wprowadzają, przenosić muszą - męczeństwo. [...] Taką to wielką, zaczerpnięta z najwyższych dziedzin duchowych wspólność widzę pomiędzy narodami tymi i w wielkie zdziwienie mię wprawia, że wspólność ta nie zrodziła dotąd miłości ${ }^{30}$.

i odtąd przetapia w ognistym piecu cierpienia. Was podzielił teraz między waszych wrogów [...], podobnie jak my zaczynacie czuć, że w życiu narodów istnieje misterium cierpienia, $\mathrm{z}$ którym wiąże się tajemnica Mesjasza. W głębinach cierpienia zrodzi się nawrócenie”.

28 Doświadczenie wewnętrzne pisarki uzewnętrzniało się etapami, ale u rdzenia było zawsze jednakie. E. Orzes sk ow a (W zimowy wieczór. W: Pisma zebrane. T. 15. Warszawa 1949, s. 172) nieraz wyrażała myśl o zasadniczej niezmienności charakteru ludzkiego: „Wszelka dusza ludzka ma podszewkę, tylko że u jednego wyjdzie ona na wierzch, a u drugiego nie wyjdzie”. W tym duchu należy też odczytać późniejsze wyznanie E. Orzeszkowej (Autobiografia $w$ listach. Wstęp A. W o d ziń ski. Warszawa 1910. Cyt. z: O sobie... Wstęp J. Kr zyż a n ow ski. Warszawa 1974, s. 99-100): „Po ojcu i matce pochodziłam z rodzin szlacheckich, posiadających tradycje męczeństw i poświęceń. [...] Dominowało nad tym wszystkim głębokie uczucie krzywdy, głębokie przekonanie, że Polska jest skrzywdzona - donkiszoterskie też pragnienie stawania w obronie skrzywdzonej", a także i inne (o ideałach najwcześniejszej młodości): „lud jako cierpienie, krzywda, powinność naprawienia krzywdy, także sztandar sprawiedliwości, wolności i w dodatku pomiędzyludzkiej równości" (E. Orze s z k owa, list do A. Drogoszewskiego, 30 III 1904. O-4 172).

E. Orze szk ow a, list do S. Peltyna, z 12 IV 1871. AEO, sygn. 333.

30 Ibidem. Fragment pierwszego zdania w tym cytacie inaczej odczytały Żmigrodzka (op. cit., s. 242) oraz Butkiewiczówna (op. cit., s. 7). Obydwie podają słowa pisarki w takiej wersji: „Stworzyłam sobie takie wyobrażenie, że każdy naród posiada udzieloną sobie wyższą siłę i mądrość, pewne wyłączne posłannictwo [...]". Moją lekcję potwierdziła I. Wiśniewska, opiekunka zbiorów AEO. 
W tym zaskakujacym cytacie mieści się i to, co Andrzej Walicki nazwał misjonizmem - przeświadczenie o szczególnych zadaniach dziejowych każdego narodu, i echo romantycznego mesjanizmu w wydaniu Mickiewicza ${ }^{31}$.

Istotną cechą mesjanistycznych poglądów autora Prelekcji paryskich było przekonanie o niezbędności cierpienia dla wybawienia narodu $\mathrm{z}$ niewoli. W myśleniu Orzeszkowej cierpienie to cena, jaką należało zapłacić, dla wykładowcy Collège de France - warunek powodzenia misji. W obu przypadkach bardziej niż o konkretne przejawy niesprawiedliwości wobec Polski chodziło o uniwersalna wartość, której mamy obowiązek strzec, powszechne prawo, które winniśmy chronić. Wspólne obojgu było przeświadczenie, że gdy gwałci się wolność w jednym miejscu, gwałci się ją w ogóle, przekreśla się wolność jako taką. Usunięcie pojedynczej narodowej krzywdy oznaczało zreperowanie całej budowli - przywracało światu równowagę moralną. W ujęciu tym prześwitywały zarysy biblijnej struktury mesjańskiej, gdzie wyzwolenie Izraela jednoznaczne było z wyzwoleniem całej ludzkości. Schemat obrazów i proroctw mesjańskich aktualizował Jastrow, gdy dowodził, że cierpienia Żydów w diasporze mają sens uniwersalny, są ważne w historii zbawienia. Idee Mickiewicza powtarzał Kraszewski, kiedy ożywiał niektóre elementy analogii polskiej i żydowskiej historii i domagał się - podobnie jak Jastrow, a także Mickiewicz uetycznienia polityki oraz stosunków społecznych. Orzeszkowa podkreślała wątek męczeństwa, bo - powtórzmy - przyjmowała cierpienie za nieunikniony koszt historycznej wierności ideałom.

Przyczyny życzliwości dla żydowskich „braci” mieściły się też we współczuciu pisarki dla wszelkiej biedy ludzkiej. W wielu nowelach autorki Meira Ezofowicza odczuwanie niesprawiedliwości, upośledzenia i krzywdy otwiera perspektywę uniwersalna - przy równoczesnym skierowaniu uwagi na konkret społeczny, zwłaszcza na społeczno-obyczajowe zróżnicowanie grup odmiennych od własnej. Pojawia się wrażliwość na cierpienie jednostki; problematyka społeczna przechodzi płynnie w moralną, splata się $\mathrm{z}$ nią ${ }^{32}$.

31 A. Walicki, Mesjanizm Adama Mickiewicza $w$ perspektywie porównawczej. Warszawa 2006 (o misjonizmie w odróżnieniu od mesjanizmu w historiozofii - zob. s. 16). Przytoczony cytat interpretuje $\dot{Z}$ mi grodzka (op. cit., s. 243) jako trawestacje widzenia historii przez A. Mi cki ew i c za w Księgach narodu i pielgrzymstwa polskiego: „Na początku była wiara w jednego Boga i była Wolność na świecie” (Dzieła. T. 6: Pisma proza. Cz. 2. Komitet red. J. Krzyża now ski [i in.]. Warszawa 1955, s. 7).

32 Wrażliwość etyczna Orzeszkowej nie podlegała nigdy dyskusji. P. Chmielowski w liście do pisarki (z czerwca 1882. AEO, sygn. 368. Cyt. za: W 517) chwalił ją „za głębokie i szlachetne odczucie bied ludzkich. [...] Takie wnikanie w dusze tych sfer, które dawniejsi nasi noweliści pomijali, [...] dowodzi i trafnego zmysłu obserwacyjnego, [...] i pięknego, dobrymi wskazówkami rozumu kierowanego serca”. Ocenę tę krytyk powtórzył w recenzji cyklu $Z$ różnych sfer („Ateneum” t. 2 $\langle 1882\rangle$, z. 6). Z podobną opinią wystapił po latach S. B r z o z o w s k i (Eliza Orzeszkowa. „Przegląd Społeczny” 1906, nr 12): „Orzeszkowa posiada dar wyczucia pod skorupą egoizmu [...] - sumienia. Sumienie jest niemal jedyną rzeczą, która Orzeszkową w świecie ludzkości obchodzi”. E. J a nk o w s k i (Europejski sukces Elizy Orzeszkowej. „Z Polskich Studiów Slawistycznych” seria 2, cz. 2 〈1963〉, s. 185) wśród przyczyn powodzenia Orzeszkowej w Rosji wymienił miłość, jaką pisarka otoczyła „znieważonych i upokorzonych”. Współcześnie na wymiar etyczny twórczości autorki Nad Niemnem zwraca uwagę B o r k ow s k a (Żydzi Orzeszkowej). Nie bez znaczenia jest tu też fakt, że dla wielu czytelników Orzeszkowa stawała się niepodważalnym autorytetem moralnym. O ile Kraszewskiego czytelnicy (w tym - młodzi twórcy żydowscy) pytali zwykle, jak pisać, o tyle do Orzesz- 
W noweli Daj kwiatek! poczucie bliskości emocjonalnej z bohaterką, stara łachmaniarką żydowska, Orzeszkowa wyraziła wprost i wymownie:

Lubię starą Chaitę, a ilekroć patrzę na nią, zdaje mi się zawsze, iż pomiędzy nią a mną istnieje jedna wielka, ścisła, nierozerwalna wspólność. Ja i ona należymy zarówno do tej ogromnej i nieszczęśliwej rodziny, która zwie się ludzkością. Krewna to więc moja i - raz jeszcze przepraszam państwa - ale i wasza także.

W dalszym ciagu autorka wyznaje, że wybrała temat z powodu umiłowania ludzi wzgardzonych i upokorzonych, zainteresowana ich trudną dolą:

Wierzajcie państwo, niczego w życiu nie pragnęłabym tak bardzo, jak znać historie całe, od początku do końca, historie wszystkich niskich, biednych, zmiętych w dłoni losu i czasu, przygarbionych i pomarszczonych, zmęczonych. [...] Znajomość [...] wielu, wielu historii podobnych stanowi dla człowieka - bogactwo serca, dla pisarza - żywy zdrój mądrości. Śmiem nawet ubolewać mocno nad pisarzem każdym, który historii takich nie ciekaw i nie świadom ${ }^{33}$.

kowej napływała korespondencja głównie z prośbami o porady życiowe - od młodych Polek, Żydówek, Rosjanek. O rosyjskich korespondencjach zob. Jankowski, op. cit.; przykłady polskie podaje Wiśniewska we wstępie do swej pracy (W 6-9); o niezwykłej korespondencyjnej przyjaźni z Blumberg zob. B or k ow s ka, Korespondencja Elizy Orzeszkowej z Malwina Blumberg (tu podstawowe pytanie brzmiało: jak żyć $z$ podwójną tożsamością, gdy twojej polskiej tożsamości nie lubią?). Dwa długie listy (z r. 1881) do B. Fajwelson (młodej asymilatorki z Pińczowa) były odpowiedzią na niepokoje adresatki związane ze smutnym losem kobiet żydowskich i nastawieniem materialistycznym żydowskiej młodzieży (O-7 54-61, 445-446). Orzeszkowa utrzymywała też korespondencyjny kontakt z młodą dziennikarką i literatką żydowską A. Korngutówną (pseud. Aniela Kallas), która wyznała, że na Elim Makowerze, Meirze Ezofowiczu i Nad Niemnem nauczyła się pisać. W jednym ze swych listów do pisarki A. Ko rn gu tó w n a (z 20 II 1894. O-8 657, przypis 3) stwierdziła: „Palące kwestie czasu - żydowską i ludową - nikt przez Wami, Czcigodna Pani, tak dobrze nie pojął. [...] Sercem zacnym odgadłaś, Czcigodna Pani, że pod tą powłoką wstrętną kryje się coś więcej niźli "Geschäft», że oni nie są tak złymi, jak o nich głoszą [...]". Autorka Chama przyjaźniła się z Aleksandrem i Jadwigą Krausharami, którzy prowadzili znany salon w Warszawie (gdzie bywali też M. Konopnicka, B. Prus, H. Sienkiewicz); w ich domu cieszyła się niebywała estymą, jej książki czytano tam na głos, na biurku Jadwigi (córki znanego finansisty i filantropa żydowskiego, Mathiasa Bersohna) stała fotografia pisarki $z$ dedykacją (listy do J. Krausharowej: O-8 19-28, 549-555). Dodajmy, że w szpitalu dziecięcym, który zafundował m.in. Bersohn, pracował później Henryk Goldszmit (J. Korczak). Odnotujmy dwa spojrzenia na owe salonowe odwiedziny i przyjaźnie: „Widziałam wiele towarzystwa żydowskiego i kilka salonów takich, w których było ono tak zlane $\mathrm{z}$ autochtonami, że pragnąc tylko wypadało, aby tak było zawsze i wszędzie. Tylko, że [...] dla mnóstwa przyczyn tak jeszcze być nie może" (E. O r z e s z k o w a, list do M. Blumberg, z 11 IV 1887. AEO, sygn. 287). Dzięki zaś krótkiej relacji J. K. Gr e g o r ow ic za (w niezachowanym liście do Orzeszkowej) dowiadujemy się, że w pewnych salonach czuł się on wprost zmuszony dementować pogłoskę, jakoby pisywała ona powieści o tematyce żydowskiej, bo została przekupiona przez Żydów! (O-8 439). Stosunek wykształconych Żydów do Orzeszkowej najpełniej oddaje adres hołdowniczy z Galicji, wystosowany z okazji jubileuszu 25-lecia pracy twórczej: „Słowa miłości ewangelią swą uczyniwszy, natchnęłaś nimi dzieci ducha swego i wysłałaś je do najdalszych i najciemniejszych zakątków naszej ojczyzny, by jako apostołowie miłości prawdą swą i szlachetnością zdobywały i pociagały ku sobie plemię izraelskie, by [...] wspólnymi siły ku wspólnym celom dążyć nauczały" (cyt. za: But ki ewi c zówn a, op. cit., s. 132-133).

33 E. Or zes zk owa, Daj kwiatek! Obrazek. „Izraelita” 1877, nr 23, s. 182. Cyt. z: Z różnych sfer. Nowele i obrazki. T. 3. Warszawa 1886, s. 113-114. Omówienie tego utworu zob. J. Dickstein ówna, Kwiatek Chaimka. „Izraelita” 1910, nr 6. Przedruk w: J. Dickstein-Wieleży ń s ka, Prometeusz-Paraklet. Studia, szkice, głosy. Warszawa 1913. 
Wrażliwość etyczna, podsuwająca pisarce te i podobne formuły programowe, leżała u podstaw kręgu tematycznego szerszego niż temat żydowski. Utwory prezentujące tę wrażliwość to dobry kontekst dla uchwycenia specyfiki podejścia Orzeszkowej do spraw żydowskich w dziełach literackich.

Dogodnym przykładem może być Obrazek z lat głodowych. W tym debiutanckim utworze widzimy wyraźnie owo przechodzenie problematyki społecznej w moralna. Obok przeciwstawienia wsi i dworu, głodujących wieśniaków oraz „pięknych panów i pań", motywu typowego dla konwencji opowiastki społecznej, zarysowuje się tam sytuacja związana $z$ wyborem moralnym, wykraczająca poza tę konwencję: Hanka oddaje ukochanemu jedzenie, sama umiera $z$ wyczerpania. „Romans u chłopów! [...] alboż oni kochają?” - to komentarz mieszkańców „białego dworu”. Komentarz autorki informuje, że opowieść wzięta jest z życia (Orzeszkowa zasłyszała ją kiedyś, teraz wspomina i odtwarza), chce przedstawić „cierpienia, [jakie] nurtują na tych dnach głębokich [...]”, ukazać „nie lśniący pozór, lecz grunt człowieczy [...]”, ,jeden z milion razy powtarzających się na ziemi dramatów" 34 . W fabularnym przebiegu tego dramatu pisarka sięga do wnętrza postaci, tam, gdzie rodzą się czyny - moralne lub nie.

„Wnętrze postaci”, ,grunt człowieczy”, „dna głębokie” te wyrażenia Orzeszkowa powtórzy przy objaśnianiu przyczyn zajęcia się tematem żydowskim w prozie. We wspomnianej korespondencji z Peltynem tak wyjawia powody swojej prośby o wskazanie odpowiednich lektur judaistycznych (cytuję obszerniejsze passusy):

Od dawna już pragnę gorąco poznajomić się gruntownie ze wszystkim, co się tyczy społeczności izraelskiej, tak ze względu na jej dzieje minione, jak co do dziś rządzących nią wierzeń i obyczajów ${ }^{35}$.

Odważyłam się w powieści [...] umieścić grupę Izraelitów, cała gminę raczej, i nakreślić życie wewnętrzne jej, tak zbiorowe, jak składających ją jednostek. Idzie mi głównie o to [...], by zajrzeć do dna tej na jednej z nami ziemi mieszkającej społeczności ${ }^{36}$.

E. Or ze s z k ow a, Obrazek z lat głodowych. „Tygodnik Ilustrowany” nry 352-353 (1866). Cyt. z: Obrazek $z$ lat głodowych. W: $Z$ różnych sfer, t. 1, s. 207. Pierwsze dwa tomy cyklu $Z$ różnych sfer Orzeszkowa zadedykowała J. I. Kraszewskiemu: „Temu, który przez pół stulecia był Pocieszycielem i Mistrzem Narodu Swego [...], zbiór ten drobnych prac mych jako hołd wielkiej czci i wdzięczności ofiaruje [...]" (ibidem, t. 2).

Orzeszkowa, list do Peltyna, z 12 VIII 1870.

E. Or ze s z k ow a, list do S. Peltyna, z 2 XI 1870. AEO, sygn. 333. Powieść, o której tu mowa, nie została ukończona. Autorka pisała o niej w liście do J. K. Gregorowicza (z 22 X 1870. O-8 12-13): „czym się teraz najbardziej zajmuję. Oto Żydami.

Proszę się ze mnie nie śmiać tak, jak ja $\mathrm{z}$ siebie często się śmieję w duchu, siedząc przy stole z żydowskim rabinem i prowadząc z nim długie konferencje o Biblii, Misznie i Gemarze. Oto wypadła mi taka konieczność, że w powieści, którą teraz piszę, Żydzi odgrywają wielką rolę; nie chciałam zaś na wzór innych powieściopisarzy brać ich ze strony tylko humorystycznej albo szachrajskiej, ale postanowiłam głębiej zbadać podstawy bytu dziwnego tego społeczeństwa i dobić się tych pobudek psychicznych, historycznych i obyczajowych, które kierują ich sprawami i postępkami. W tym celu przeczytałam $z$ dziesięć dzieł traktujących o Żydach, ale mi tego było mało [...]. [...] udało mi się pochwycić pewnego rabina, który nie posiada się od radości, że może komuś udzielić swej talmudycznej wiedzy. [...] Przez dwa szabasy chodziłam do szkoły i mam przyobiecane, że będzie mi dozwolonym asystować przy pierwszych sądach, jakie się będą odbywać przed rabinem. Nie ręczę, czy po Grodnie nie rozejdzie się wieść, że przyjmuję żydowską religię - ale ja się z tego 
Utwierdzam się w przekonaniu, że dla dwóch ludów losem na jednej ziemi umieszczonych wzajemne poznanie się i ocenienie stanowi jedno z najważniejszych zadań moralnych i społecznych. [...] trzeba tylko umieć spojrzeć w głębię, pominąć pozory lub podnieść je treścią rzeczy ${ }^{37}$.

Co oznaczały te autodyrektywy? Nakaz patrzenia od wewnątrz na jednostkę czy grupe społeczną nie należał z pewnością do standardów scjentystycznego myślenia o człowieku. Przeciwnie. Antropologia pozytywistów badała zachowania jednostek czy grup społecznych raczej od strony przyczyn niż pobudek, kładła nacisk na różnorakie determinacje historyczne i społeczne. Obca jej była teza o względnej autonomii jednostkowego czy zbiorowego indywiduum jako ośrodka wyborów moralnych i postaw życiowych. Pomijała rolę sumienia w postępowaniu i znaczenie wartości decydujących o przyjętych kryteriach oceny wydarzeń. Wrażliwość etyczna Orzeszkowej przełamywała to podejście. Zwłaszcza przy wyborze i przedstawianiu postaci $z$ niższych kręgów społecznych. Tych traktowanych jako drugorzędne na kartach literatury, odzieranych często z podmiotowości w życiu społecznym ${ }^{38}$.

Za typowe utwory o takiej tematyce można uznać nowele $\mathrm{z}$ 3-tomowego zbioru $Z$ różnych sfer (znalazła się w nim też opowiastka Daj kwiatek!). I tu problematyka stricte społeczna otwiera perspektywę moralną, przepływa w zagadnienie losu i doli ludzkiej, w fabule zarysowują się podstawowe kwestie ludzkiej egzystencji. Postacie są kulturowo zróżnicowane, reprezentują - schodzące coraz bardziej w dół - poziomy ówczesnej struktury społecznej. To przeważnie owi „maluczcy”, ludzie „zewnętrzni”, nazwani tak m.in. w reportażach $Z$ pożogi. Osoby o ograniczonych możliwościach umysłowych i skromnej pozycji materialnej. Autorka wychodzi jednak poza uwarunkowania bytowe tych ludzi. Bada ich nastawienie wobec losu. Analizuje postępowanie względem bliźnich. Obdarza cnotami wyrosłymi na gruncie „miłości miłosiernej”. Ich postawy egzystencjalne często motywuje religijnie. Zawiedzeni życiem, zachowują spokój ducha, skrzywdzeni - przebaczają krzywdy, w przeciwnościach

śmieję, a czego się nauczę i o czym się dowiem, to już będę wiedziała i umiała. A za to w powieści mojej Żydzi powinni wyjść naturalnie i głębiej pojęci niż dotąd".

Passus cytowany przez Całą (op. cit., s. 223). Fragment wzmiankowanej powieści znajduje się w AEO (sygn. 815), istniejące ułamki scharakteryzował Jankowski w przypisach do zacytowanego listu (O-8 545-546). Wynika z nich, że miała ona przedstawiać dwa typy żydowskie: jeden mądry, religijny, głęboko interpretujący święte pisma, i drugi człowiek - zaradny w interesach, często balansujący na granicy prawa. Długi czas informację o tej powieści odnoszono do Eli Makowera (1874) (np. Butkiewiczówna) lub Meira Ezofowicza (1878). Z podanego cytatu wynika, że Orzeszkowa utrzymywała kontakty nie tylko z Żydami zasymilowanymi Grodna i Warszawy. Starała się poznać także tradycyjnych Żydów i ich sprawy z autopsji, nie poprzestawała na czytaniu odpowiedniej literatury. Wykaz książek i broszur o problematyce żydowskiej, będących w posiadaniu pisarki, sporządziła na podstawie jej notatek z $1880 \mathrm{r}$. (AEO, sygn. 243) A. Wojtyczek (Tradycja i religia Żydów w literaturze polskiej XIX wieku. Warszawa 2012). Zob. też w przypisach do publikowanego tu listu 2 (przypisy 1, 11) informacje o staraniach w dotarciu do odpowiednich lektur. Najdokładniej na ten temat zob. W, passim. Orzes z k owa, list do Peltyna, z 12 IV 1871.

38 Or zes zkowa (O postępie, s. 90-91) zdawała się przyjmować, iż warunkiem cnoty (gotowości do dobrych uczynków) jest wolna wola. Nie była jednak konsekwentna, „własnowolność” i „samowiedność”, w jej myśleniu - pojęcia bliskie wolnej woli, wiązała nierzadko z wiedzą i oświatą raczej niż ze zmysłem moralnym oraz stopniem wolności i podmiotowości człowieka. 
poświęcają się dla innych, bliski im jest etos wyrzeczenia i ofiary. W obrazie stosunków „pomiędzyludzkich” i jednostkowych zachowań, jaki tu znajdujemy, błyskają refleksy ideałów ewangelicznych i miłości biblijnej.

Podobny zamysł - przeniknięcia do fundamentów opisywanego świata - odkrywamy w beletrystyce Orzeszkowej poruszającej tematy żydowskie. W odróżnieniu od tekstów publicystycznych, gdzie przy całej wielostronności ujęcia (rzadkiego w dyskursie pozytywistów) dominuje podporządkowywanie sprawy żydowskiej sprawie polskiej, w prozie widać starania o zajęcie pozycji odmiennej. Dbałej o to, by własny głos prezentowanego środowiska był jak najbardziej słyszalny. W publicystyce Orzeszkowa przyjmowała, iż rozwiązanie kwestii żydowskiej leży w polskim interesie. Ułożenie dobrych stosunków z Żydami miało uczynić z nich sprzymierzeńców w walce $\mathrm{z}$ zaborca. Nadanie im praw i skorzystanie $\mathrm{z}$ ich umiejętności praktycznych sprzyjałoby modernizacji i przyszłej niepodległości. W tym celu należało poznać Żydów (Orzeszkowa wracała do tego postulatu wielokrotnie, także w listach, m.in. do Peltyna). Uważała, że w polskim społeczeństwie niewiele się wie o owej izolującej się - i wyizolowanej - mniejszości wyznaniowej. Autorka wyrzucała polskim pisarzom, że temat traktuja powierzchownie i lekceważąco, a opinii publicznej, że w najlepszym wypadku poprzestaje na znajomości, jaką daje kontakt z Żydami w interesach.

Potrzebę zapoznawania polskiego społeczeństwa $z$ realiami codzienności żydowskiej głosił również obóz integracjonistów, o czym po części już wspominałam. Szczególnie głośno brzmiał apel o podawanie religii żydowskiej po polsku. „Jutrzenka” i „Izraelita”, gdzie najwięcej rozprawiano na ów temat, stanowiły zresztą same w sobie, jako fakty prasowe, realizację tego ogólnego postulatu. Była to rzecz ważna wobec ogromnej roli, jaką odgrywała wówczas prasa. Można było liczyć, iż do czasopism żydowskich zajrzy też publiczność polska. Wiara w sprawczą moc słowa drukowanego dawała nadzieję, że czytelnicy ci zrewidują swoje negatywne opinie. Solidna wiedza o Żydach, o ich dążeniach, zamiarach, samoświadomości, pozwoli - sądzono - na odwojowanie zastarzałych stereotypów, pomoże w obdarzeniu tej populacji szacunkiem. Także dzięki zrozumieniu tego, co łączy obydwie religie, bez pogardzania tym, co dzieli.

Podobnie myślał Kraszewski, gdy zachęcał młodych żydowskich adeptów pisarstwa do autoprezentacji. Wedle dawnego zawołania Joachima Lelewela: „dajcie się poznać mowie polskiej, jak jesteście w sobie" ${ }^{39}$. Spodziewanie się i tu, i tam, że

J. Le le w e 1, Sprawa żydowska w r. 1859 w liście do Ludwika Merzbacha [...]. Poznań 1860, s. 29. O literaturze polsko-żydowskiej (żydowsko-polskiej) zob. Listy Jakuba Goldszmita do Józefa Ignacego Kraszewskiego, s. 165-166 (zwłaszcza przypisy 53-58). Gruntowniejszy opis zjawiska zob. Z. Koł o d zi i j s k a: Czymjest literatura polsko-żydowska $w$ świetle dyskusji w „Izraelicie”. W zb.: Żydowski Polak, polskiŻyd. Problem tożsamości w literaturze polsko-żydowskiej. Red. A. M ol i s a k, Z. Kołodzi ej ska. Warszawa 2011; „Izraelita” (1866-1915). Znaczenie kulturowe i literackie czasopisma. Kraków 2014. Podobnie jak Kraszewski, o potrzebie literatury tworzonej po polsku przez Żydów o Żydach pisała W. Marrené (Morzkowska) (Kwestia żydowska w powieści wspótczesnej. „Tygodnik Ilustrowany” nr 201 〈1879〉): „Bez porównania ważniejszymi [...] są pojęcia i desiderata samychże Izraelitów, złożone w powieści, niżeli te, które tworzą w ich imieniu i na ich rachunek chrześcijanie, chociażby nawet natchnieni najszczerszymi sympatiami”; za dobry przykład takiego piśmiennictwa autorka podawała powieści M. Meyersonowej. Również wobec literatury dla 
ekspresja literacka utwierdzi podmi otowy kształt integracji, pomoże wyrwać ruch spod kontroli zewnętrznej, oswobodzić od narzuconych warunków, da moc, by przeciwstawić się instrumentalnej postawie otoczenia. I oswoić obie społeczności $z$ prawomocnością takiego podejścia.

Orzeszkowa, traktująca swój literacki program poznawania Żydów świadomie jako służbę zadaniom narodowym, znalazła się - o dziwo - bardzo blisko tego nurtu żydowsko-polskiego piśmiennictwa, którego wolą było uwzględniać nie zewnętrzną, lecz własna perspektywę. Wynikało to z przyjęcia moralnych zobowiązań literatury. Przekazywanie w literackim słowie współczucia ludzkiej biedzie i niesienie pociechy dotkniętym przez los okazywało się w końcu w twórczości Orzeszkowej równie ważne, jak funkcja świadczenia na rzecz zbiorowości.

Autorka Nad Niemnem włożyła ogromny wysiłek, by zgłębić realia środowiska żydowskiego. I to, czego się nauczyła ( $\mathrm{z}$ książek i z autopsji), umiejętnie spożytkowała $\mathrm{w}$ prozie. Poznawczy autorytet literatury wpisany w zasadę realizmu dawał gwarancję, że w opowiedzianych historiach czytelnicy zobaczą prawdziwy obraz świata żydowskiego, odczytają je jako dokładne odwzorowanie rzeczywistości. Orzeszkowa wszelako - jak wiemy - nie obserwowała żydowskiej kultury neutralnie. Przyglądała się jej z pełnym pasji osobistym zaangażowaniem, przez pryzmat doświadczeń córki narodu podbitego. $Z$ tą głęboka empatią, którą wolno potraktować - sądząc po owocach - jako odkrywcze źródło wglądu w tę kulturę, cenne narzędzie poznania, połączone $z$ wyobraźnią i niemałym kunsztem literackim.

Żydowskie narracje Orzeszkowej świadczą o podobnym zamiarze, jaki leżał u podstaw Obrazka $z$ lat głodowych i nowel z cyklu $Z$ różnych sfer. Autorka ujawniła go zresztą wprost w zacytowanych fragmentach listów do Peltyna. Nie było to zaciekawienie egzotyką, zaabsorbowanie naskórkową powierzchnią faktów. Przedstawiając społeczny kształt życia żydowskiego pisarka wiedzie czytelnika w głąb. Stara się pokazać poza zewnętrznymi formami odmiennej kultury to, jak postrzegają ją jej uczestnicy, jej samowiedzę, jej „sobość”. Orzeszkowa dowodzi, że nie tylko wi e, ale i rozumie. Ta podwójna intencja daje w wyniku odmianę prozy, którą nazwać można opowieścią etnograficzną ${ }^{40}$.

Widać to najlepiej w kreacji bohaterów. W postawach i wyborach moralnych większości $z$ nich nie znajdziemy śladu konwencjonalnych rysów przedstawicieli tej grupy. Nieliczne postacie nacechowane negatywnie to wizerunki Żydów „źle zasymilowanych", występujące zresztą także w piśmiennictwie żydowsko-polskim, np. w prozie Malwiny Meyersonowej czy w demaskatorskich fragmentach publicystyki „Izraelity”. Podporządkowane hasłu: nasze wady sami będziemy piętnować, wkroczymy na arenę publiczną według swoich określeń. W nieżydowskich utworach

ludu czasami wyzbywano się drażniącego paternalizmu: „Nie wywyższanie jednych kosztem drugich, ale podniesienie ludu w jego własnym przekonaniu powinno być stałym celem literatury ludowej” (Literatura dla ludu. „Przegląd Tygodniowy” 1880, nr 13).

40 O powieści etnograficznej zob. H. D u ć - F aj fe r, Etniczność a literatura. W zb.: Kulturowa teoria literatury. Główne pojęcia i problemy. Red. M. P. Markowski, R. Nycz. Kraków 2006. E. Pr o k o p - J a n i e c, Powieść etnograficzna a kultury mniejszości. W zb.: Kulturowa teoria literatury. 2: Poetyki, problematyki, interpretacje. Red. T. W ala s, R. Ny cz. Kraków 2012. 
Orzeszkowej owej autokrytyce odpowiadał wielostronny dystans wobec własnej grupy.

Natomiast u pierwszoplanowych protagonistów żydowskich pisarka decydującą rolę przyznawała wartościom, które oni sami wypowiadali jako swoje. Odkrywała, że specyfikę omawianego środowiska stanowi religia. Większość jej wyznawców Orzeszkowa wyposażyła w cnoty, w jakie obfitowały postacie prezentowane w zbiorze $Z$ różnych sfer. Tam pozwalała tylko się domyślać ich źródła (co czytelnik czyni zresztą bez trudu). Tu ich rodowód nazwała po imieniu. To - „przykazania synajskie”. W efekcie między człowiekiem prosty m a człowiekiem żydows kim wznosiła mosty porozumienia na filarach zbliżonej etyki. Odkrywała „wspólność”. W różnicach dostrzegała równość i podobieństwo. Łączyła - ekumenicznie - świat żydowski i świat chrześcijański.

Prezentacja owych postaci to często ich autoprezentacja. Gedali, bohater noweli pod tym tytułem, wzorowany na rzeczywistym mieszkańcu miasteczka Wołpa, niedaleko Grodna ${ }^{41}$, pokazuje siebie poprzez opowieści z Talmudu. To mędrzec, „duch cierpienia”, w starodawnych historiach, jakie przedstawia, zaznajamiając napotkanych chrześcijan $z$ midraszowym dziedzictwem, znajduje lekarstwo na nawiedzające go nieszczęścia. Spokój ducha wobec utrapień losu wypływa z przeświadczenia, że wszystko, co się wydarza, pochodzi od Boga, jest darem, który należy przyjąć. Gedali z pokora wypełnia przepisy religijne. Stary Judel, ojciec Elego Makowera, odsłania wnętrze swej duszy powołując się na tradycję jako na ostoję życia, trwałe oparcie pośród chaosu. Kiedy radzi synowi, jak postapić w trudnej sytuacji, sięga do jej zasad etycznych. To wybór uczciwości i życzliwych uczuć dla wszystkich, także dla gojów. Kto żydowski „grunt stracił”, jest ,jak człowiek, który nie ma o co oprzeć się [...]” - w ten sposób przekonuje syna, by pomógł chrześcijańskiemu sąsiadowi ${ }^{42}$.

Wżywanie się od środka w świat żydowski najznamienitsze rezultaty przyniosło - nietrudno zgadnąc - w Meirze Ezofowiczu. Tu też najpełniejszy wyraz znalazła problematyka religijna oraz ukryta za nią dialektyka tego, co swojskie i co obce.

Pozytywiści milcząco zakładali nieważność czy też małoważność różnic religijnych $-\mathrm{z}$ punktu widzenia interesów polskiego społeczeństwa. Głosili tolerancję i zasadę równości wyznań jako istotne elementy demokracji i liberalizmu ${ }^{43}$. Ale do głowy im nie przyszło zainteresować się judaizmem jako podstawową więzią wspól-

41 E. Orzeszkow a, Gedali. Obrazek wiejski. „Dziennik Łódzki” 1884, nry 208, 211, 216. Przedruk (niektóre pt. Kramarz. Obrazek wiejski) w: W zimowy wieczór. Warszawa 1888; Meir Ezofowicz. Silny Samson. - Gedali. - Ogniwa. Warszawa 1899. Pisma. T. 3. Omówienia tej noweli zob. m.in.: „Przegląd Tygodniowy” 1884, nr 46; „Izraelita” 1885, nr 19 (w rubryce Światła i cienie). O pierwowzorze tytułowej postaci zob. passusy w listach E. O r ze s z k ow ej do L. Méyeta z lat 1884 i 1891 (O-2 24, 46-47) oraz pracę K. K o n c z e w s k i ej Eliza Orzeszkowa a Grodzieńszczyzna-studium pamięci (w zb.: Sekrety Orzeszkowej. Red. G. B orkows ka, M. Ru d kow s ka, I. W i śni ew s ka. Warszawa 2012, s. 176).

42 E. Orzeszkowa, Eli Makower. Powieść. T. 2: O ziemię. Warszawa 1876, s. 343 (pierwodruk: „Tygodnik Ilustrowany” nry 340-365 〈1874〉).

43 Na tolerancję i równoprawność wyznań kładli też nacisk integracjoniści, wysuwali te postulaty także pod adresem strony żydowskiej i w duchu wiary (nie agnostycyzmu, jak, przeważnie, pozytywiści). Np. S. Pelty n w artykule Nasza intolerancja („Izraelita” 1868, nr 22) pisał: „Minęły czasy ciemnoty i intoleracji! 
noty, która właśnie się reformuje. Problem żydowski jawił się im jako problem wyłącznie społeczny; polonocentryzm, dodatkowo uwarunkowany nienormalnym położeniem politycznym, stawał się w tej optyce niemal nieuchronny.

Inaczej Orzeszkowa. W beletrystyce potrafiła dostrzec dylematy i rozterki typowe dla ówczesnej zmieniającej się zbiorowości żydowskiej jako takiej. Interesowała się Żydami dla niech samych. W historii o Meirze głównym tematem uczyniła nie stosunki między Polakami a Żydami - to wątek w powieści uboczny. U jej podstaw leży pytanie, czy istnieją wewnątrz społeczności żydowskiej jakieś siły zdolne oczyścić ją ze skostnienia i fanatyzmu, przywrócić tej wspólnocie dawne soki żywotne, wigor i szlachetnośćc4.

Orzeszkowa nie wątpiła w wielkość Izraela. W przytoczonym fragmencie listu do Peltyna dała wyraz przekonaniu, że polega ona na historycznej zasłudze upowszechnienia idei jedynobóstwa oraz na ugruntowaniu jej implikacji moralnych w kulturze. Ponawiała w ten sposób oceny Tadeusza Czackiego, Lelewela, Mickiewicza $^{45}$.

W Meirze Ezofowiczu miasteczko Szybów to jakby metafora współczesnej kultury żydowskiej. Wszystkie tkanki życia przenika tu tradycja. Jej specyficzna postać, zadekretowana przez rabina, rzutuje na całą organizację społeczną, instytucje,

Nienawiść religijna, dzieląca przez tyle wieków rodzinę ludzką na nieprzyjazne obozy znika, ustępując miejsca uczuciom pobłażania i humanizmu.

Opatrzność Boża, wiodąc ród ludzki ku celom sobie znanym, rozświeciła mu drogę pochodnią nauki, przy której religie, poznawszy wspólny swój pierwiastek, wspólny cel, do którego dążą, poczęły się nawzajem szanować i ręka w rękę ku ognisku prawdy i dobra kroczyć".

Odpowiadało to nawoływaniom do porzucenia nienawiści do gojów w innych artykułach pisma.

Zauważyła to B u tki ewic zówn a (op. cit., s. 59), nie wyciagnęła jednak z tej obserwacji dalszych wniosków. Od innej strony, zgodnie z przyjętą tu optyką, spojrzał na powieść A. J. C o hn (Elizie Orzeszkowej, autorce „Meira Ezofowicza” w hołdzie. „Izraelita” 1906, nr 7) w opublikowanej po latach recenzji:

„Jakże to się stało, że, gdy wszystko, instynktem zoologicznym wiedzione, nienawidzi typów różnych, kocha tylko podobne, [...] ty, Pani, zatrzymałaś oko, pełne miłości, na upośledzonych, brudnych, nędznych, o rysach odrębnych, odmiennej mowie i odmiennych obyczajach? [...]

Odkryłaś ludzkie serca, ludzkie cierpienie, [...] odkryłaś bliskie ci serce - wydzierające się z tęsknotą ku światłu - serce Meira...”

Pochlebne recenzje o Meirze pisali m.in. T. T. J eż („Nowiny” 1879), J. K o ta r b iń s ki („Przegląd Tygodniowy” 1879, nr 2: „przeciwstawiał się [Meir] antysemickiemu zdziczeniu i egoistycznym instynktom rasowym”, „działał uszlachetniająco na umysły”), J. I. Kra s ze w s ki („Biesiada Literacka” nr 173 〈1879〉). Zob. L. B elm o n t, Żydzi Orzeszkowej. (O „Meirze Ezofowiczu”). „Wędrowiec” 1906, nr 11, s. 212: „Idąc od zew nątrz i notując wszystko w pamięci - [...] potrafiła autorka zajść ogromnie daleko w głąb, w e w n ą tr $z$ do targanych bólem trzew dzieci Izraela [...]".

T. C z a c ki, Rozprawa o Żydach. Wilno 1807. Cyt. z: Rozprawa o Żydach i Karaitach. $Z$ dodatkiem wiadomości o życiu i pismach autora. Z. 1. Kraków 1860, s. 3: „Księgi kanoniczne tego ludu [...] są księgami, które religia chrześcijan między święte liczy wyrocznie”; „od nich Dekalog i objawienie, od nich miłość bliźniego. [...] Kórz się chrześcijaninie przed Bogiem w bożnicy Izraela, jak się korzysz we własnym kościele" (s. 1). Podany fragment cytował z aprobatą Lelewel w swej broszurze Sprawa żydowska w r. 1859 w liście do Ludwika Merzbacha [...]. Zob. też M. B u try mowicz, Sposób uformowania Żydów polskich w pożytecznych krajowi obywatelów (1789). Wstęp H. S zy n km a n. Warszawa 1917, s. 20: „Dziesięcioro Bożego przykazania równie u Żydów jest rzeczą świętą, jak u nas". Książki te Orzeszkow a (O Żydach i kwestii żydowskiej, s. 390) wymieniała jako swoje lektury. Zob. też Mickiewicz, op. cit. 
zwyczaje, zachowania jednostek. Nieodparty autorytet duchowego przywódcy zniewala umysły, narzuca kształt wiary, kult obrzędów, normy regulujące dnie powszednie i święta. Przepisy nakazują eliminowanie wszystkiego, co przychodzi z zewnątrz, oddzielają swoich od obcych, zagłuszaja przykazania synajskie.

W kreacji tytułowego bohatera Orzeszkowa pokazuje, jak bardzo jest możliwa moralna i społeczna odnowa tej kultury dzięki jej własnym zasobom. Meir to buntownik. Uosabia sprzeciw wobec takiego kształtu tradycji, jaki przybrała ona współcześnie. Bohater powołuje się na głębsze jej warstwy. Cytuje słowa Biblii (Tory), nie Talmudu. Przyjaciele mówią o nim: „wzorowy syn Izraela”, ten, co „przykazania synajowe wiernie pełnił”. Jest litościwy i przebaczający, ujmuje się za prześladowanymi, pomaga biednym, broni obcych. Ceni wyżej nakazy moralne Dekalogu niż skrupulatne przestrzeganie kultu. Pozostaje przy własnym rozumieniu wiary. Chroniąc niezależność duchową, znajduje oparcie w tych pokładach rodzimego dziedzictwa, gdzie nie uznaje się dogmatów, pozwala się na swobodną interpretację świętych ksiąg. Razem z przyjacielem o podobnym nastawieniu zawołałby:

Nie powiedzieliśmy: „Oddajemy wam [tj. rabinom] w niewole dusze nasze”, albowiem każdemu synowi Izraela wolno jest szukać Pana w sercu swoim i słowa Jego tłumaczyć wedle rozumu swego ${ }^{46}$.

Co chce osiagnąć? Dowiadujemy się o tym pośrednio - z mowy pradziada, którą Meir odczytuje na zgromadzeniu zwołanym przez rabina:

Izraelu! [...] ty jesteś wielkim narodem! Ty pierwszy spomiędzy narodów wszystkich zobaczyłeś w niebie Boga jedynego, a na ziemi usłyszałeś w huku gromów i blasku błyskawic dziesięć ogromnych słów, na których, jak na dziesięciu opokach, inne ludy przez pokolenia wszystkie budują wschody do słońca doskonałości! [...] W udręczeniach i nędzach srogich opadła $\mathrm{z}$ ciebie stara wspaniałość twoja i rozmnożyły się jako gwiazdy grzechy i nieprawości twe, a Jehowa, Bóg twój, patrząc na ciebie, zapytuje z gniewem: „Jestże to ten sam lud mój wybrany, którego zaręczyłem z Sobą w prawdzie i łasce? Azaliż on Zakonu mego inaczej strzec nie umie, jak słowami ust, które sprzeciwiają się uczynkom rąk jego? Azaliż Zakon ten widzi on tylko w ofiarach, spiewach, modłach i kadzidłach, a nie we wstępowaniu na tę wielką drabinę, którą objawiłem we śnie słudze memu, Jakubowi [...]”47.

E. Orzeszkowa, Meir Ezofowicz. Posł. J. Krzyżanowski. Przypisy M. Bokszczanin. Warszawa 1954, s. 394. Pierwodruk: Meir Ezofowicz. Powieść z życia Żydów. „Kłosy” 1878. Kolejne wydanie, $z$ podtytułem: Powieść $w$ dwóch tomach (t. 1-2. Warszawa 1886). Autograf - brulion, ofiarowany Méyetowi, zawierający dedykację: „Najlepszemu z przyjaciół - Autorka”, zaginął w czasie okupacji. Nie udało się ustalić, $z$ jakiego tłumaczenia pochodzą fragmenty z Biblii cytowane przez Meira i - co za tym idzie - czy sa wierne. Jeden z nich: „Niepotrzebne mi modlitwy ani ofiary wasze! Kto uciska biednych, ten krzywdzi Stwórcę" - wydaje się odwołaniem do wersetu z Księgi Ozeasza (w: Pismo Święte Starego i Nowego Testamentu w przekładzie z języków oryginalnych. Oprac. Zespół Biblistów Polskich [...]. Biblia Tysiaclecia. Wyd. 3, popr. Poznań 1988): „Miłości pragnę, nie krwawej ofiary, / poznania Boga, bardziej niż całopaleń” $(\mathrm{Oz} 6,6)$. Podobne słowa przytoczył Kram s z ty k (op. cit.) w mowie inaugurującej otwarcie ochronki żydowskiej: „Albowiem milsza mi jest dobroczynność nad ofiarę na ołtarzu zarzniętą". Podam tu jeszcze dwa inne fragmenty biblijne wplecione w wypowiedź Meira, tłumaczącą, dlaczego udaremnił czyn współziomków wymierzony w chrześcijanina: „Musiałem zrobić, co każdy prawy Izraelita zrobić powinien, bo napisane jest: "Niech cudzoziemiec żyje pomiędzy wami, jak gdyby był zrodzon z potomków Izraelowych", a w innym miejscu napisane jest: "Jeżeli milczeć będziesz, na twoją głowę spadną nieszczęścia Izraela"” (O r z e s z k ow a, Meir Ezofowicz, s. 137). 
Usytuowanie historyczne tej przemowy i jej struktura wpisuja się we wspomniane myślenie analogiami. Meir jest ostatnim w łańcuchu pokoleń, który nosi w sercu pradawną ideę odrodzenia narodu, pragnie tego, co nie udało się poprzednikom. Czy osiaga cel? Nie. Przegrywa. Odnowa macierzystej wspólnoty, przywrócenie jej godnego miejsca w kole wolnych społeczeństw, to wielkie marzenie romantyczne. Meir ma w sobie coś z bohatera romantycznego. Dąży do niemożliwego. Postawiony jest w sytuacji heroicznego wyboru moralnego: albo pozostanie wierny sobie kontynuując dzieło przodków zakończone klęską, albo ugnie się i ulegnie żądaniom większości. Nie poddaje się, odchodzi. Przyjmuje konsekwencje kolejnej porażki. „Dobry on był i miłosierny” 48 - powie o nim tłum już po klątwie rabina, której skądinąd przyklasnął.

Meir - ten „inny”, odmienny pod względem religii i kultury, staje się równy i podobny nam. Równy i podobny podwójnie - w płaszczyźnie wartości moralnych oraz wyobrażeń romantycznych o roli narodów i jednostek, ścigających niezmierzony horyzont ideału ${ }^{49}$.

Czytając Meira Ezofowicza trudno przypuścić, by „zlanie się” było czymś więcej niż tylko stylistycznym zwrotem zaczerpniętym z przyrodniczej wyobraźni epoki. Owszem, zawierało pewną ideologię. Ale i u Orzeszkowej, i w obozie integracjonistów (gdzie także sięgano po to określenie, choć nieraz i krytykowano, podobnie jak po tamtej stronie ${ }^{50}$ ) chodziło o coś głębszego niż obrona partykular-

Ibidem, s. 372.

Orzeszkowa mocno by się zdziwiła, gdyby jej powiedziano, że syjoniści inspirowali się polskim romantyzmem politycznym (podobnie jak ideami pracy u podstaw i pracy organicznej). M. Buber na jednym $z$ kongresów syjonistycznych (1898) ogłosił, że kultura może zastąpić brak państwowości, stać się fundamentalnym spoiwem narodu żydowskiego i gwarantem jego ocalenia. Bliski temu filozofowi Ahad Ha-Am propagował w tej roli pracę jako czynnik, który nie tylko coś wytwarza, ale uszlachetnia człowieka i podtrzymuje substancje narodu. Obaj, podobnie jak np. Aron Dawid Gordon czy Natan Bystrycki, wysuwali program syjonizmu kulturowego, kładli nacisk na potrzebę odrodzenia przez język, kulturę, jednostkowy wysiłek moralny i pracę właśnie. Dla Orzeszkowej praca miała podobne znaczenie; nie tylko przysparzała dóbr i pozwalała bogacić się społeczeństwu, lecz stwarzała też nowego człowieka. Wartość pracy w wymiarze społeczno-moralnym podkreślał Brzozowski, oddziaływania były tu wzajemne (zob. R. L o e w, Stanisław Brzozowski wśród lektur syjonistycznych. W zb.: Kwestia żydowska w XIX wieku). Sprawozdanie z odczytu Bystryckiego w Warszawie redakcja polsko-żydowskiego pisma „Ster” (1937, nr 43) opatrzyła mottem ze S. Żeromskiego: „Polska odrodziła się z krwi i pracy męczenników po to, żeby na miejscu, gdzie stała ciemnica niewoli, rozpostarło się najjaśniejsze pracowisko postępu”. W tym samym lokalu co Bystrycki miał odczyt Korczak (sprawozdanie z odczytu zob. ibidem), który wraz z całym nurtem „nowej pedagogiki” zalecał pracę jako ważne narzędzie wychowania i ulepszania świata. Nurt w syjonizmie zwany rewizjonizmem stawiał na walkę zbrojną - z pełną świadomością, że jej cel przerasta siły pokolenia.

Problemy z terminologią (wówczas i dzisiaj) omawia wnikliwie A. Jagodzińska w artykule Asymilacja, czyli bezradność historyka. O krytyce terminu i pojęcia (w zb.: Wokół akulturacji i asymilacji Żydów na ziemiach polskich. Red. K. Zi el ińs k i. Lublin 2010) oraz we wstępie do wspomnianej książki Pomiędzy. Od strony socjologicznej (wraz z przytoczeniem zagranicznej literatury przedmiotu) naświetla rzecz H. D a t n e r-Ś p i e w a k w pracy Ta i tamta strona. Źydowska inteligencja Warszawy drugiej połowy XIX wieku (Warszawa 2007). Zob. też M. W o dziń s ki, Oświecenie żydowskie $w$ Królestwie Polskim wobec chasydyzmu. Dzieje pewnej idei. Warszawa 2003. W swoim opracowaniu Cała (op. cit.) omija wprawdzie kłopotliwe problemy terminologii, proponuje za to doskonałą typologię asymilacji i podkreśla rolę Haskali. 
nych interesów. Jakub Goldszmit używał zamiennie $z$ omawianym zwrotem wyrażenia „wzajemne zbliżenie” ${ }^{51}$. Nie był w tym odosobniony. I lepiej chyba utrafił w intencje ożywiające żydowską prozę pisarki - tak jak ją dzisiaj odczytujemy. Cel stanowiło spotkanie, wyjście sobie naprzeciw, obustronna wymiana doświadczeń. Wyrażając się bardziej współcześnie - zbudowanie międzytekstowej przestrzeni dialogu, gdzie przy afirmacji własnej identyczności szuka się płaszczyzny porozumienia.

Ważnym polem była tu religia. Od zarania swej publicznej aktywności autorka Meira Ezofowicza nie była tak obojętna wobec rodzimego dziedzictwa religijnego jak większość pozytywistów. Choć od młodości uczestniczyła w różny sposób w procesie laicyzacji polskiej kultury. Propagowane przez siebie normy osobowe wywodziła w znacznej mierze $z$ etyki świeckiej. Za dobro uważała to, co pożyteczne dla społeczeństwa. Wychwalała „cnoty proste”, bliskie moralności mieszczańskiej miały one sprzyjać unowocześnieniu kraju. Promowała postawy obywatelskie podporządkowanie praw jednostki interesom ogółu. Zasady etyki utylitarnej wiązała $z$ organiczną wizją społeczeństwa, w którym harmonijnie współistniałyby ze sobą zróżnicowane grupy ludzkie. Chodziło Orzeszkowej o taki kształt stosunków „pomiędzyludzkich”, gdzie uprawnienia zależałyby od powinności ${ }^{52}$. I w tym też kontekście - powtórzmy - rozważała w publicystyce sprawę żydowską, przekraczając w wytworach wyobraźni literackiej ograniczenia, jakie owa sprawa narzucała współczesnym.

Przyznawała się do agnostycyzmu, lecz nie taiła wątpliwości, czy w praktyce społecznej idea Boga nie jest konieczna - jako sankcja moralna lub pociecha „smutnych i samotnych”. Kusiła ją wiara w ludzkość, przeświadczenie, iż wcieleniem najwyższych wartości człowieka jest sam człowiek, obiegowa wtedy religia ludzi oświeconych, przejęta m.in. z filozofii Auguste'a Comte'a ${ }^{53}$.

Zaaprobowaniu takiego rozwiązania sprzyjałby krytyczny stosunek do Kościoła katolickiego. Orzeszkowa, podobnie jak inni ówcześni intelektualiści (również Kraszewski), zarzucała Kościołowi wiele: podtrzymywanie stanowego porządku społecznego, zabijanie wolnej myśli, tresurę dusz, także - instytucjonalne zhierarchizowanie. Natomiast, tak jak Kraszewski, pisarka ceniła Ewangelię, niejedno z jej

51 Mam tu na myśli dwa artykuły Jakuba Goldszmita i fragmenty: „Dążyć do zupełnego pod każdym względem zlania się ludności żydowskiej z resztą mieszkańców” (Parę słów o wychowańcach Żydach Szkoły Rolniczej w Nowej Aleksandrii. „Izraelita” 1881, nr 22); „Chęć służenia poczciwej sprawie wzajemnego zbliżenia” (Do czytelników. „Kalendarz dla Izraelitów na Rok 5642 [...] $1881 / 82 ")$.

52 Zob. na ten temat G. B or kow s ka, Publicystyka Elizy Orzeszkowej jako szkoła myślenia obywatelskiego. Wstęp w: Orzes z k ow a, Publicystyka społeczna. W innym miejscu G. B or k ows k a (O etyzacji dyskursu publicznego. List do kobiet niemieckich Elizy Orzeszkowej. W zb.: Etyka i literatura, s. 31) tak scharakteryzowała ów fragment projektu moralnego Orzeszkowej: „Etyką obowiązku rządzi swoista ekonomia, równy rachunek uprawnień i czynów koniecznych, odpowiedniość między "mam prawo" a "powinienem", [...] równowaga między gestem brania a gestem oddawania, między egoizmem a altruizmem, między ruchem dośrodkowym i odśrodkowym”.

53 Swoje rozterki E. Orzeszkowa wyraziła w liście do J. Karłowicza, z 18 (30) VIII 1884 (O-3 66-67). Odpowiedź adresata brzmiała: „w co wierzyć? Na to tymczasem innej odpowiedzi nie znam, jak ta, którą dał Comte: ludzkość" (O-3 402-403). 
wskazań wcielała - jak pokazywałam - w postępowanie literackich postaci; osobę Chrystusa przedstawiała ze czcią.

Interesowała pisarkę religia jako przedmiot wiedzy. Orzeszkowa sporo czytała książek religioznawczych. Wszelako jej pragnienie zrozumienia tego fenomenu nie brało się $z$ lektur ${ }^{54}$. Te były tylko wsparciem. Spojrzenie na egzystencję ludzką jako na dramat oraz doświadczenie wszechobecności cierpienia w świecie stymulowały ową szczególną wrażliwość moralną i dyspozycję serca, oczekujących przyjęcia rozstrzygnięć i pociech religijnych. Ta skłonność wewnętrzna, rozmaicie wyrażana, nie w pełni siebie świadoma, szukająca dopiero dróg i ścieżek (,po labiryncie różnych wierzeń ludzkich błądziłam, drogi i ścieżki różne zmieniając [...]”55), stała się podnieta przy pisaniu Meira Ezofowicza.

Wgłębiając się w inny świat, Orzeszkowa doceniła - powtórzę - jego równość i zarazem odmienność. Jednocześnie dodam: zrozumiała też lepiej siebie. Obcowanie $\mathrm{z}$ postacią Meira posunęło naprzód proces samopoznania - także w stosunku do religii. Autorka Nad Niemnem - czytelniczka lektur judaistycznych, prenumeratorka „Izraelity”, interlokutorka grodzieńskiego rabina, twórczyni postaci pobożnych Żydów, stawała się kimś innym, niż była dotąd. Czy raczej - budziło się w niej to, kim była wcześniej. Wolno tu mówić o swoistym kole hermeneutycznym. Wrażliwość na ludzką niedolę sprzyjała epifanii Innego, objawieniu niepowtarzalnego „ty” bohatera w całej jego wielkości i biedzie, doświadczenie to zaś pozwoliło odsłonić jej i nam strony osobowości pisarskiej do tej pory zakryte. Czytanie i mówienie o świecie żydowskim tworzyło podatny grunt, by przekroczyć świadome ,ja”, wyzbyć się rezerwy wobec religii objawionej ${ }^{56}$, uchwycić miejsce i znaczenie religii w różnych dziedzinach życia. W sferze moralności odnoszącej się do jednostek i grup - jako wspólne dziedzictwo judeochrześcijańskie. W obszarze egzystencji jako poświadczona tą samą tradycją wizja pozaświatowej siły wpływającej na bieg ludzkich spraw - podstawa religijnej koncepcji życia, którą w późniejszych latach Orzeszkowa przyjmowała jako własny drogowskaz ${ }^{57}$ (w twórczości eksponowała m.in. w narra-

54 Zob. S. Fit a, Eliza Orzeszkowa w poszukiwaniu religii. W zb.: Problematyka religijna w literaturze pozytywizmu i Młodej Polski. Świadectwa poszukiwań. Red. ... Lublin 1993.W pracy tej mowa m.in. o studiach religijnych pisarki, obszerniej o lekturze dzieł E. Renana. Problematyce religijnej w twórczości Orzeszkowej poświęcił sporo uwagi J. To mkowski (Mój pozytywizm. Warszawa 1993, rozdz. Barok, gotyk, religia serca). Sprawa intrygowała wielu badaczy, także autorkę monografii Orzeszkowa. Młodość pozytywizmu. Ostatnio zastanawiała się nad problemem G. B o r k o wska (Orzeszkowa - szkic do biografii duchowej. W zb.: Prus i inni. Prace ofiarowane profesorowi Stanisławowi Ficie. Red. J. A. Malik, E. Paczoska. Lublin 2003), sugerując, że jednym z ogniw religijności pisarki był panteizm.

E. Orzeszkowa, list do T. Bochwica, z 24 III 1909. O-5 167.

56 W. P a n a s w książce Pismo i rana. Szkice o problematyce żydowskiej $w$ literaturze polskiej (Lublin 1996) nazwał Meira Ezofowicza powieścią tranzytywną, mając na myśli wykroczenie w narracji poza horyzont ideowy Orzeszkowej. Podobną myśl znajdziemy u Borkow ski ej (Publicystyka Elizy Orzeszkowej jako szkoła myślenia obywatelskiego, s. 34): „Okazuje się [w przypadku Orzeszkowejl, że uczciwy stosunek do "innych" odbudowuje poprawne, istotne relacje ze "swoimi». Im bardziej otwieramy się na zewnątrz, tym bardziej rośnie nasza siła "środka"."

57 Wyraźnie to widać w zapiskach dzienniczka prowadzonego przez E. O r z e s z k ow ą (Dnie. Oprac. I. Wi śn i ew ska. Warszawa 2001) w latach 1898-1904. Edytorka zauważa, że wiele jego partii to przede wszystkim „wyraz p o k o ry wobec losu. Bóg postrzegany jest jako ten, który daje i odbiera. Orzeszkowa dziękuje Mu zarówno za dobre, jak i złe chwile ("Dzięki Ci, Boże, Panie, za 
cji o Gedalim). W kulturze - fenomen służący pogłębianiu duchowości, osłabiający pokusy płytko pojętego postępu cywilizacyjnego, sfera pytań o zagadkę dramatu człowieka, jego cierpień i przeznaczenia ${ }^{58}$.

\section{Kalendarze}

Przygoda Jakuba Goldszmita z „Kalendarzem dla Izraelitów” warta jest baczniejszej uwagi. Nie mam na myśli osobistych nieporozumień z pierwotnym pomysłodawca, Adolfem Cohnem (list 2). Chodzi mi o rozziew między intencjami a recepcją. Kraszewski, tak wielbiony przez Jakuba Goldszmita, odmówił uczestnictwa i zganił publikację. Orzeszkowa wprawdzie nadesłała zamówiony tekst, ale milczała, gdy poproszono ją o ocenę ogólną. Krytycznie przyjęła „Kalendarz” prawie cała prasa związana z obozem pozytywistów ${ }^{59}$. W rezultacie wydawca, mimo iż planował opublikowanie następnych roczników, zrezygnował $z$ tego. $Z$ przygotowanych materiałów sporządził kalendarz zwykłego typu.

Na czym polegała wyjątkowość tego izraelskiego kalendarza? Jego datowanie omówiłam z grubsza w komentarzach (list 1, przypis 1). Tu wspomnę, że wyróżniała je rachuba lat. Podawano je podwójnie: „od stworzenia świata”, jak w tradycji żydowskiej, i od narodzin Chrystusa, jak w chrześcijaństwie. Dwoisty również był układ miesięcy: na tej samej stronicy widniały: kolumna żydowska ze świętami żydowskimi i nazwami miesięcy po hebrajsku, wykazem czytań z Tory i postami na dany okres oraz dwie tej samej wielkości kolumny chrześcijańskie (katolicka i prawosławna). Kalendarz miał zatem dwojakiego adresata i dwojaki cel. Zaznajamiał polskiego odbiorcę $\mathbf{z}$ cyklem świąt przyjętym u Izraelitów, żydowskiemu zaś - dawał szansę uszanowania świątecznego czasu chrześcijan. To oczywiste. Ale prócz tego - co może mniej oczywiste - tej drugiej kategorii odbiorców stwarzał okazję do przeżywania świąt i żydowskiego rytmu liturgicznego po polsku, dowartościowania wyznawanej religii, pozbycia się piętna obcości. Czy sugerował też równorzędność obu wiar?

Zestawienie dwóch sposobów liczenia czasu pod jedną okładką niosło ze sobą ważne przesłanie. Rachuba od początku świata nie oznaczała, rzecz jasna, uwzględniania faktu fizykalnego, odwoływała się do opisu biblijnego. Czas liczono od momentu kreacji poprzez sumowanie lat życia kolejnych pokoleń według danych chronologii biblijnej. Naturalnie, nie chodziło o dosłowność ani o szczegóły, lecz o znak. Ogłaszał on, że żydowski przekaz ma charakter uniwersalny, dotyczy całej

wszystko, co boli, i za wszystko, co pociesza" - całkowicie poddając się Jego woli” (ibidem, s. 21). Wiśniewska zauważa, że modlitewne inwokacje Orzeszkowej w tym dzienniczku wydają się bliższe Staremu Testamentowi dzięki wyłącznym przywoływaniu imion: „Pan”, „Bóg” i „Ojciec” (ibidem, s. 22).

58 Zob. E. Orzeszkowa, Panu Janowi Karłowiczowi. Przedmowa w: Melancholicy (1896). Red. J. Krzyża nowski. T. 1. Warszawa 1949, s. 7, 13: „Oddaleni od nieba i nieśmiertelności, spostrzegliśmy [...], że wiedza nie podaje młota do rozbijania obręczy tajemnic, które ściskają nas i niepokoją [...]”; , „Najpewniej też cierpimy nienadaremnie. Na jakimś warsztacie olbrzymim jesteśmy kółkami biorącymi udział w dokonywaniu dzieła niepojętego [...]”.

59 Zob. na ten temat osobny przypis w części 2 z Listów Jakuba Goldszmita do Elizy Orzeszkowej, która zostanie opublikowana w przyszłym roku. 
rodziny ludzkiej, nie tylko jednego narodu. „Uroczystość, która dziś obchodzimy [tj. dzień Nowego Roku, Rosz Haszana], jest uroczystością całej ludzkości; obchodzimy dziś urodziny świata!” - przypominano w „Jutrzence” to, co wiedział dokładnie każdy pobożny Żyd ${ }^{60}$. Obrzęd Nowego Roku podkreślał $z$ całą wyrazistością ów dwoisty wymiar wyznawanej religii, wyrażony liczeniem lat i kształtem liturgii (nie zawsze ujawniany równie jasno w korpusie tekstów). Alians wyobrażeń oświeceniowych i religijnych, tak często spotykany w retoryce niektórych integracjonistów, tutaj zdaje się mieć swoje źródło.

Datowanie „Kalendarza” Jakuba Goldszmita stanowiło ważny krok w kierunku pojednania tradycji z nowoczesnością. Tradycja miała określać żydowską tożsamość przez odpowiednie rozczłonkowanie i usensowienie czasu, w jakim się żyje. Nowoczesność zaś tkwiła w tym, że treści sakralne wyrażano w mowie, jaką winni się byli posługiwać na co dzień wszyscy mieszkańcy Królestwa. „Żyd widząc świętości swoje w języku krajowym traktowane, przestanie się uważać za obcego [...]" - pisano w „Jutrzence” ${ }^{61}$, wyprzedzając niejako nadzieje twórców „Kalendarza”. Goldszmit akcentował przy tym $z$ dumą, że hamuje zalew niemieckich kalendarzy, których wydawano wówczas sporo dla miejscowych wykształconych Żydów.

20 lat później problem stosunku tradycji i nowoczesności przybrał na sile. Wielu zastanawiało się, jak żyć z podwójną tożsamością, wielu odchodziło od żydostwa, szerzył się indyferentyzm religijny. Polskość w różnorakich wymiarach zagarniała coraz bardziej uczucia jednostek wyemancypowanych. Jak zatamować rozchwiania emocjonalne, łagodzić wahania i watpliwości, zapobiec rozproszeniu - na te pytania kalendarz Goldszmita próbował odpowiedzieć. Ale ani jedna, ani druga strona nie była gotowa, by zaakceptować to swoiście ekumeniczne przedsięwzięcie.

On sam wraz z Cohnem należał do tej grupy polonizujących się Izrelitów, których cechowała równie mocna i jasna identyfikacja $z$ żydostwem, jak więź emocjonalna $z$ polskością. Obaj umieli pogodzić wymagania wiary $z$ wymogami postępu i dążeniami narodowymi (Cohn brał udział w powstaniu styczniowym, Goldszmit - w konspiracyjnych działaniach postyczniowych). Rodzima tradycja nie była dla nich zbiorem luźnych elementów, spośród których można by wybierać bez większego uczuciowego zaangażowania. Popularyzowali piśmiennictwo pokazujące życie własnego środowiska otoczone szacunkiem - czy to sami je uprawiając, czy zachęcając do tego innych. Troszczyli się o dobre imię współziomków: Jakub wraz z bratem Józefem kreśląc życiorysy „,wsławionych Izraelitów”, Cohn propagując usilnie teksty pisane o Żydach przez Żydów. Zganieni w polskiej prasie za szerzenie separatyzmu (czyżby ci Żydzi bardziej byli „wsławieni” przez to, że Żydami są?), nie wycofali się w obrażone milczenie. W kolejnych szkicach biograficznych pisali o mniej znanych Polakach, chwaląc ich za osiagnięcia oraz przychylny stosunek do Izraelitów. Jakub Goldszmit nawet w dalekiej Ameryce próbował szerzyć wiedzę o swojej dobrodziejce i korespondentce. jewski, 54 komentarze do „Tory” dla nawet najmniej religijnych spośród nas. Kraków 2004, s. $20-21$.

61 Słówko o literaturze żydowskiej. „Jutrzenka” 1861, nr 26, s. 208. 
Nie zniechęcił się też po porażce pierwszego „Kalendarza”. Ten rodzaj publikacji wykorzystał do innych celów. W Królestwie wydawano masę kalendarzy z tekstami dla odbiorców o zróżnicowanym poziomie wykształcenia. Niektóre, zbliżone charakterem do pisemek dla ludu, pełniły ważną funkcję w akcjach oświatowych.

Współpracownik „Izraelity” doskonale uchwycił ów edukacyjny potencjał kalendarzy, kiedy podjął się następnych ich wydań, teraz już datowanych „normalnie”. Jak inni publicyści obu pism spodziewał się, że podniesienie oświaty nadwątli niejeden przesąd antyżydowski u niewykształconych chrześcijan. $Z$ drugiej strony, aktywnie wspierał żydowskie szkolnictwo świeckie. Kalendarze Jakuba Goldszmita, wspomagane połączonymi siłami polskich i żydowskich autorów, mieściły się w nurcie wychowawczych działań społeczników obu nacji pragnących modelować zachowania przez popularyzację wiedzy. Redefiniowały tradycję, jej nosicieli przestrzegały przed przyjęciem, bodaj nieświadomym, jakichś fragmentów tożsamości narzuconej czy też zdystansowaniem się lub zaniechaniem własnej. Oddziaływały w obydwie strony. Miały oświecać „nieoświeconych” i zarazem utrzymać przy tradycji już wykształconych Żydów. Tym ostatnim podsuwały za wzór ofiarność polskich działaczy społecznych, trudzących się wokół poprawy umysłów i położenia ludności $z$ niższych sfer ${ }^{62}$.

Kalendarze Orzeszkowej odgrywały paralelną rolę. Na poziomie faktów dzieliły los izraelskiej edycji Jakuba Goldszmita. Napotykały podobne trudności: „Kalendarz Litewski” dla ludzi „prostych” oraz „Kalendarz Wileński” dla „ukształceńszych”63. Opublikowane przez wileńską księgarnię, oba okazały się sporym sukcesem komercyjnym. Orzeszkowa szykowała kolejne roczniki. Ale nie dość, że pozwolenie na ich pierwszą edycje uzyskano $z$ największym trudem ${ }^{64}$, od razu zostały one ostro zaatakowane (podobnie jak całe wydawnictwo). Oskarżał moskiewski tygodnik „Ruś” za szerzenie polskiej kultury i katolicyzmu ${ }^{65}$. Następne roczniki nie wyszły - mimo zebranego materiału.

Obydwa te zespoły wydawnictw popularnych - Goldszmita i Orzeszkowej pozwalają uchwycić szersze zjawisko: analogiczną sytuację polskiej i żydowskiej formacji inteligenckiej. Tej, z której wyrastał po obu stronach wieloimienny etos ofiarnego inteligenckiego społecznikostwa. Cechujący się - najogólniej mówiąc poczuciem obowiązku wobec spraw publicznych. Pełnienie służby społecznej

Był to motyw stale przewijający się w piśmiennictwie polsko-żydowskim. Zob. np. Rok ubiegły. „Jutrzenka” 1861, nr 3: „Mamy przed sobą wzór godny naśladowania, widzimy, jak klasy wyższe rodaków naszych chrześcijan połączonymi siłami dźwigają ciężar umoralnienia i oświecenia proletariatu miejskiego i wiejskiego nie wyłączając i żydowskiego”. Dyskutowano też o metodach oświecania, czasami biorąc za przykład różnorodne próby odejścia od modelu paternalistycznego, spotykane w polskiej prasie.

63 Określenia adresatów pochodzą z listów pisarki do L. Méyeta (marzec 1881. W 421) oraz J. Karłowicza (styczeń 1881. W 434).

64 Zob. na ten temat E. Orzeszkowa, listy do L. Méyeta, kwiecień-grudzień 1880. O-2 1012. Zob. S. Rosiak, Księgarnia „E. Orzeszkowa i S-ka” w Wilnie. 1879-1882. Wilno 1938, s. $81-100$.

65 [A. K.], Budzenie polskości w Kraju Zachodnim. Z powodu wydania w Wilnie Kalendarza Litewskiego. „Ruś” 1882, nr 1. Cyt. za: W 486. 
wpisywało się nieuchronnie we wzorzec żydowskiego integracjonisty. Wśród postulatów owego wzorca znajdowało się nie tylko jednostkowe zbliżenie do polskiej większości. Równoległy wymóg stanowiło dobro całej wspólnoty, występującej jako podstawowe odniesienie dla tożsamości zbiorowej. Hasło świeckiej oświaty skierowane do żydowskich mas odpowiadało w dużej mierze akcjom polskich społeczników, którzy dzięki kształceniu „maluczkich” mieli nadzieję utrzymać polski lud przy polskości. Zdaniem „postępowców”, oświata miała polepszyć położenie materialne biedoty żydowskiej, poszerzać horyzonty, formować nastawienia, uczyć zachowań obywatelskich, otwierać na świat. W polskich działaniach edukacyjnych chodziło o rozbudzenie świadomości narodowej tam, gdzie polska książka nie docierała wcale, o zespolenie dążeń ludzi nieuczonych $z$ aspiracjami niepodległościowymi inteligenckiej elity, o ocalenie jedności narodowej w różnorodności. Poczucie odpowiedzialności za otaczający świat, za stan umysłów niewykształconego ogółu było tu i tam wspólne. W obozie żydowskich reformatorów zbiegało się ono nadto $z$ etosem judaizmu i doktryna tikun olam - naprawy świata.

Wileńska inicjatywa pisarki nie była jedynym narzędziem jej walki o polskość $\mathrm{w}$ wymiarze godzącym tradycję $\mathrm{z}$ nowoczesnością. Swej publicznej aktywności autorka Meira Ezofowicza przydzielała podobne zadania jak te, które wyznaczała żydowska dobroczynność. I tu, i tam intencją działań stawało się zbiorowe samookreślenie się, wyrwanie się ze stanu podporządkowania, utwierdzenie się wobec przeszłości, samopoznanie i prezentacja na zewnątrz, wreszcie zmniejszenie podziału na elity i masy jako niezbędny warunek modernizacji całego organizmu społecznego. W ostatecznym rachunku chodziło: po jednej stronie - o służbę niepodległości, przeciwstawienie się rusyfikacji; po drugiej - o zahamowanie procesu uszczuplania wspólnoty, rozpływania się jej członków w morzu innowierców.

Organizując polską społeczność w Grodnie do gaszenie pożaru, doprowadzając do zrzucenia rosyjskiej kurateli nad działalnością charytatywną w miejscowej Kasie Ubogich, wykonując planową pracę oświatowo-kulturalną w domu i patronując tej na mieście czy też współdziałając z żydowskimi dobroczyńcami rozsianymi po kraju, Orzeszkowa dawała przykład, że mimo zniewolenia można dostrzec siebie jako suwerenny podmiot własnych działań, wyrazić się w czynach budujących podstawy samorządnego i obywatelskiego społeczeństwa - choćby w niewielkiej skali grodzieńskiego powiatu.

Pisownia w listach została zmodernizowana według obowiązujących obecnie zasad. Pozostawiono wszakże formę imienia „Jakób” - jako charakterystyczną dla tamtej epoki. Zachowano także układ nagłówków oraz końcowych formułek grzecznościowych. Miejsca nieczytelne oznaczone są trzema kreskami w nawiasie kwadratowym [---].

Teksty opracowano na podstawie listów przechowywanych w AEO przy IBL PAN w Warszawie (sygn. 800). 
Warszawa, d. 11 sierpnia $1881 \mathrm{r}$.

[Nadruk:]

Redakcja

„Kalendarza Izraelskiego”

w Warszawie

\section{Szanowna Pani!}

Jako kierujący częścią wydawniczą „Kalendarza Izraelskiego” ${ }^{1}$, zmuszony jestem, acz z prawdziwą przykrością, zakomunikować Szan[ownej] Pani niemiłą wiadomość, że cenzura ogromne w artykule Szan[ownej] Pani porobiła szczerby ${ }^{2}$. Jestem doprawdy zbyt silnie zmartwiony okolicznością tą, a to tym bardziej, że, o ile wnoszę, takiż sam los spotka chyba i prace p. Kościałkowskiej ${ }^{3}$, czyli - proszę, nie zechciej Pani wziąc to za czczy komplement - dwa najlepsze nasze „nabytki” literackie.

Jak bądź jest, nie upadam jeszcze na duchu, mam bowiem nadzieję, że dzięki osobistym stosunkom uda mi się może w cenzurze jako tako srogich zoilów, czy może katonów, ubłagać ${ }^{4}$.

Przy sposobności proszę też uprzejmie racz Szan[owna] Pani nadesłać łaskawie ogłoszenie o swej księgarni i wydawnictwach ${ }^{5}$ do zamieszczenia w „Kalendarzu Izraelskim". O prospekt bardzo proszę, rad bym albowiem zamieścić je na pierwszej zaraz stronicy działu anonsowego ${ }^{6}$.

Przysyłam przy niniejszym cyrkularz ${ }^{7}$, prospektu albowiem nie mam pod ręką. Żydzi tutejsi bardzo życzliwie zapowiedź wydawnictwa przyjęli, jednakże nie spieszą poprzeć je podawaniem anonsów. Wydanie odznaczać się będzie możliwie niską ceną, nie przedsięwzięliśmy albowiem spekulować, ale, w miarę sił, szerzyć zdrowe pojęcia: światła i wiedzy.

Żałuję mocno, że w okolicach Pani nie ma znajomych Izraelitów. A może też i oni poczuliby się w obowiązku wesprzeć to, co jedynie chęcią służenia „ogólnemu dobru" wywołane zostało.

Przykro mi bardzo było, żem nie miał szczęścia osobiście poznać Szan[owna] Panią za ostatnia Jej bytnością w Warszawie ${ }^{8}$. Wina jednak tego leży po części na barkach przyjaciela mego, p. Leopolda Méyet ${ }^{9}$, który mi przyrzekł zarekomendować Pani, a przyśpieszywszy swój wyjazd, uczynić tego nie mógł

Czekam tedy łaskawej odpowiedzi wraz z anonsem, zwrotem i zostaję z prawdziwym szacunkiem i poważaniem

JGoldszmit

[Nadruk pionowy z lewej strony:] Adres Redakcji: Jakób Goldszmit, Dzielna nr 6 w Warszawie

[Nadruk pionowy z prawej strony:] Wydawcy: Adw[okat] przys[iegły] Ad. J. Cohn - Jakób Goldszmit

1 Publikacja ta ukazała się pod tytułem „Kalendarz dla Izraelitów na Rok Religijny (Zwyczajny) od Stworzenia Świata 5642, czyli od Narodzenia Chrystusa. 1881-1882”. Niżej zapis: „Rok ten zaczyna się w sobotę dnia 24 września 1881, a kończy we środę dnia 18 września 1882. / Warszawa. / Nakładem wydawcy. / Skład główny w redakcji "Kalendarza" Leszno 65”. Na stronie kontrtytułowej 
data cenzury (26 września) i informacja: „Drukiem Józefa Ungra, ul. Bednarska 5”. Dział kalendarzowy obejmował okres od września 1881 do września 1882 i dzielił się na trzy kolumny: izraelską, prawosławną, rzymskokatolicką; w każdej zaznaczano odpowiednie święta, w ostatniej, katolickiej - także imiona świętych patronów. Na okładce: „Wykaz świąt chrześcijańskich, osobno wydrukowany, może być wyjęty i służyć za kalendarzyk pugilaresowy”. Na końcu, jak zwykle w kalendarzach ówczesnych, reklamy, wykazy instytucji itp.

Dział literacko-publicystyczny zawierał: Jakuba Golds z mita Do czytelników; E. O r ze s z k owej Słowo wstępne; wiersz W. Go muli c ki g go „El mole rachmim” (Boże pełen miłosierdziamodlitwa za zmarłych); Jakuba Goldszmita (pierwodruk: „Izraelita” 1867, nr 23) Głośny a nieznany. Szkic biograficzny (o jałmużniku wileńskim - Szymelu Kaftanie, z przytoczeniem wiersza Kwestarz starozakonny 〈pierwodruk: „Teka Wileńska” 1858〉, napisanego przez W. Kor otyńs ki e go, a poświęconego tej postaci); B. As pis a Z pieśni wschodnich. (Fragment z „Sulamity”); dra K. Hertza Na czasie (szkic publicystyczny o potrzebie zbliżenia Żydów i chrześcijan); dra J. W e in b e r g a Zgon proroka. (Fragment $z$ „Mesjady”); M. B ał u c k i e g o TypowaŻydówka. (Obrazek z życia), oraz rubryki: Rozmaitości (zebrał i ułożył-ig- [Jakub G ol d s z m i t]) i Aforyzmy, niepodpisane (tu m.in. utwory poświęcone wierze i religii, np. „Monoteizm jest słońcem duchowym w systemacie planetarno-religijnym...”). Wśród ogłoszeń - tekst reklamowy (podpisany: -ig-), polecający pensjonat dla dzieci izraelskich z uwzględnieniem „rytualnych przepisów” i możliwością nauki hebrajskiego, muzyki i innych przedmiotów na miejscu. „Kalendarz” ukazał się w październiku, z niewielkim opóźnieniem w stosunku do daty dziennej żydowskiego święta Nowego Roku (Rosz Haszana); cena wynosiła około 35 kop.

2 Chodzi o wspomniane tu już Stowo wstępne, napisane w odpowiedzi na list A. J. C o h n a (z 20 V 1881. AEO, sygn. 800), zawierający szkic zamierzonego przedsięwzięcia i zaproszenie pod adresem pisarki: „Od wielu lat noszę się z myślą wydawania "Kalendarza Izraelskiego" [...], czuję potrzebę zogniskowania prac kwestii żydowskiej dotyczących w książce, bądź co bądź w odróżnieniu od czasopism mającej wartość nieprzemijająca. [...] Program tego wydawnictwa zakreśliłem sobie taki: po części kalendarzowej nastąpi 1) kronika roczna: przegląd najważniejszych wydarzeń w życiu Żydów w kraju; 2) artykuł o historii Żydów (o ile możności najnowszej); 3) o stanowisku społecznym Żydów (artykuł); 4) życiorysy ludzi zasłużonych dla sprawy żydowskiej; 5) szkice powieściowe [...]; 6) poezje. [...] Racz, Szan[owna] Pani, nadesłać do "Kalendarza" artykuł z działów powyżej wymienionych, stosownie do własnego wyboru”. Pisarka przyrzekła artykuł i nadesłała go do redakcji w czerwcu. Zob. komentarze: E. Orzeszkowa, Publicystyka społeczna. T. 1. Wybór, wstęp G. B or kow s ka. Oprac. edyt. I. W i śn i ew s ka. Kraków 2005, s. 339-341 (tu też przedruk 〈po raz pierwszy tekstu $\mathrm{z}$ „Kalendarza”).

Adolf Jakub C o h n (1843-1906), prawnik, publicysta, adwokat przysięgły. Absolwent warszawskiej Szkoły Rabinów oraz wydziału prawa Szkoły Głównej w Warszawie. Brał udział w powstaniu styczniowym. Debiutował w piśmie „Jutrzenka. Tygodnik dla Izraelitów Polskich” (1861-1863). Długoletni członek redakcji i jeden z najaktywniejszych publicystów następcy „Jutrzenki” - pisma „Izraelita”, wydawca i redaktor „Gazety Kolejowej” (1881). Współpracował także z polskimi periodykami, m.in. z „Gazetą Sądową Warszawską” (był jej współzałożycielem razem z Ignacym Radlińskim), „Kłosami”, „Prawdą”, „Gazetą Polską”. Publikował też książki z dziedziny prawa (m.in. Rzut oka na prawodawstwo mojżeszowe, 1865). Niestrudzony rzecznik literatury polsko-żydowskiej, orędownik myśli rzuconej przez Markusa Jastrowa, propagowanej przez „Jutrzenkę”, popieranej przez Józefa Ignacego Kraszewskiego, zamierzał zorganizować towarzystwo dla jej krzewienia; wracał do tego pomysłu w rozlicznych artykułach ogłaszanych w „Izraelicie”, sprawdzał w praktyce: powieść Zbawca (1862, tłumaczona $z$ niemieckiego), osnuta na podaniach ludu praskiego getta, wiersz Głos Żydów do dzieci polskich w almanachu „Gwiazdka” (1863), Żydowskie szczęście, obrazek z życia (1866), Pod klątwa urodzenia. Szkice i obrazki („Izraelita” 1880, nry 44-51). Opracował fragment książki $Z$ dziejów Gminy Starozakonnych $w$ Warszawie $w$ XIX stuleciu (Warszawa 1907), która została wydana po jego śmierci.

Po wycofaniu się Cohna partnerem Orzeszkowej pozostał Jakub Goldszmit, on też poprowadził rzecz do końca. Ostateczny kształt wydawnictwa odbiegał jednak od ambitnych zamiarów przedstawionych w liście, oryginalna część kalendarzowa była pomysłem zastosowanym już wcześniej. Zob. „Kalendarz dla Starozakonnych w Królestwie Polskim na Rok 5585, a podług Ery Chrześcijańskiej, od 23 Września 1824 do 13 Września 1825”; „Kalendarz Żydowski 1862/64, Lata według 
Kalendarza Hebrajskiego 5623-5624”; „Kalendarz dla Izraelitów na Rok od Stworzenia Świata 5631 i 5632”, przez Izaaka Kramsztyka, kaznodzieję synagogi przy ul. Nalewki (Warszawa 1870-1871) oraz wychodzacy przez rok tylko „Kalendarz dla Izraelitów na Rok Przestępny 1877/78, od Stworzenia Świata 5638” (pod redakcją Fabiana Straucha, kierownika szkoły dla chłopców żydowskich, drukującego w „Izraelicie”) - układ trójkolumnowy podawał datowanie żydowskie, rzymskokatolickie i prawosławne (kalendarz z 1825 r. obywał się bez tego ostatniego), dwa pierwsze kalendarze nie miały części literacko-publicystycznej, w pozostałych obszerne części literackie zawierały materiały o żydowskich świętach i historii żydowskiej. Podobny kalendarz od drugiej połowy lat siedemdziesiątych XIX w. publikował też „Izraelita” w maleńkiej ramce przy końcu każdego numeru: dwukolumnowy, tygodniowy, z podziałem na część żydowską i chrześcijańską. W artykułach o świętach żydowskich podawano także datę chrześcijańską i polskie nazwy (np. Pesach - Wielkanoc, Jom Kippur - Dzień Odpustu, bar micwa - konfirmacja). Podobnie postępowano, gdy tematyka świąteczna pojawiała się w ogłaszanych tam utworach literackich - nie skąpiono rozbudowanych informacji o historii i znaczeniu poszczególnych świąt w żydowskim kalendarzu liturgicznym; starano się pokazywać bliskie związki judaizmu z chrześcijaństwem. Przekonanie to wyrażano nieraz wprost: „Bo stosunek dwóch wyznań, chrystianizmu i judaizmu z natury rzeczy co najmniej jest braterski [...], dwa te wyznania mają te same zasady z jednej księgi religijnej czerpane, te same żywią uczucia i nadzieje” (Rok ubiegły. „Jutrzenka” 1863, nr 3). Przedstawiano też chrześcijaństwo jako „młodszą córkę” „synajowej wiary”, kontynuującą misję Izraela szerzenia jedynobóstwa ([S. Pelty n], Monoteizm. „Izraelita” 1866, nr 12).

3 Wilhelmina Zy ndra m-Koś ciałkowska (1844-1926), literatka, tłumaczka, zaprzyjaźniona z Orzeszkową od najmłodszych lat. Mieszkała w Grodnie. Wspólnie z Orzeszkową napisały powieść Złota hrabinka. Opowiadanie lekarza („Ateneum” 1877, z. 8). W późniejszym okresie przyjaźń osłabła, stosunki towarzyskie pozostały jednak nadal żywe, a grono wspólnych znajomych (także tych z Warszawy) było niemal identyczne. Również bliska znajoma Cohna, który prawdopodobnie pośredniczył w publikacji dwóch jej tekstów na łamach „Izraelity”: Sandalfon (z Longfellowa) (1877, nr 17) oraz Cmentarz żydowski w Newport (z Longfellowa) (nr 25). Zapewne to on złożył jej propozycję napisania czegoś do „Kalendarza”, ale zamówiony szkic nie ukazał się. O przyczynach można przeczytać w liście 2.

4 Praktyka cenzury w ówczesnej Rosji opierała się na ustawie o cenzurze i druku z r. 1857, wielokrotnie nowelizowanej (1865, 1886, 1890 i później), uzupełnianej licznymi okólnikami, tajnymi i jawnymi, wytycznymi i zarządzeniami. Organizacyjnie cenzura obejmowała Główny Zarząd Cenzury i komitety w większych miastach gubernialnych (np. Warszawski Komitet Cenzury, Wileński Komitet Cenzury); na tzw. ziemiach zabranych (w tym na Litwie) była surowsza niż w Królestwie, silniejsza była tam presja rusyfikacyjna. Zob. S. Kr z e m i ń s ki, Dwadzieścia pięć lat Rosji w Polsce (1863-1888). Zarys historyczny. Lwów 1892. - S. Wigura [F. Rawita-Gaw r ńs ki], Dziesięciolecie cenzury rosyjskiej w Królestwie Polskim (1880-1891). Kraków 1892. - Akta cenzury. Fragmenty protokołów Warszawskiego Komitetu Cenzury. Wybrała, przeł., krótką kroniką cenzury warszawskiej (1815-1915), wiadomością o aktach Warszawskiego Komitetu Cenzury i notami opatrzyła H. S e c o m s ka. Warszawa 1966. - Świat pod kontrola. Wybór materiałów z archiwum cenzury rosyjskiej $w$ Warszawie. Oprac. M. Pru s s a k. Warszawa 1994. - Piśmiennictwo, systemy kontroli, obiegi alternatywne. Red. J. Ko s te cki, A. B r o dzk a. T. 1. Warszawa 1997. We wprowadzeniu do Świata pod kontrola czytamy: „Pisarze i wydawcy wszelkimi dostępnymi środkami, czyli także za pomocą łapówek, prowadzili pertraktacje z urzędnikiem odpowiedzialnym za książkę" (s. 7). W Warszawie cenzor W. M. Iwanowskij zabronił wystawienia scenicznych przeróbek Meira Ezofowicza (w adaptacji H. O dyń ca〈H. A m elińs ki e go〉, 1889) i Eliego Makowera (w adaptacji E. Kośmińskiego, 1891). W obu przypadkach motywacja była ta sama: pojednanie polsko-żydowskie jest szkodliwe dla sprawy rosyjskiej, zatem „p. Iwanowskij zaproponował wystawienia tego dzieła zabronić” (cyt. za: J. Kulc zy c ka - Sal o n i, Życie literackie Warszawy w latach 1864-1892. Warszawa 1970, s. 212-213). Rosyjska cenzura bardziej była czujna wobec przedstawień teatralnych (zwłaszcza ludowych) niż w stosunku do druków.

5 Wzmiankowane wydawnictwo, istniejące w Wilnie w latach 1879-1882, przy ul. Świętojańskiej 2, było tzw. księgarnią nakładową, tj. mającą pozwolenie na handel książkami i ich publikowanie (we wszystkich językach oprócz żydowskiego). Stowarzyszona z nią biblioteka miała z kolei prawo do książek w każdym języku poza polskim (nielegalnie wypożyczała jednak literaturę polską). Orzesz- 
kowa kierowała działalnością nakładową firmy, utrzymywała kontakty z autorami, edytorami, księgarzami. W wydawnictwie tym najczęściej korzystano z drukarni J. Blumowicza w Wilnie, książki wysyłano do cenzury w Warszawie. Opublikowano około 20 pozycji, w tym wiele dzieł Orzeszkowej (jako pierwszy ogłoszono tekst programowy: Patriotyzm i kosmopolityzm 〈1879〉, jako ostatni - rozprawę O Żydach i kwestii żydowskiej 〈1882〉), poezje M. Konopnickiej, utwory M. Bałuckiego, studia P. Chmielowskiego, także wydawnictwa kalendarzowe (,Kalendarz Litewski na Rok 1882”, „Kalendarz Wileński na Rok 1882”) i zeszytowe (cykliczne Kartki satyryczno-humorystyczne, tzw. Alfabet (cztery zeszyty, piąty zatrzymała cenzura〉). Księgarnia, o której mowa, od początku wywoływała liczne kontrowersje. Za przeciwstawianie się rusyfikacji została zamknięta przez władze carskie (,jako podtrzymująca polska agitację jest szkodliwa dla kraju”, W 497), niektórych pracowników represjonowano, Orzeszkowa otrzymała zakaz (coraz to przedłużany) opuszczania Grodzieńszczyzny. „〈... Otwarcie księgarni〉 drobniutka to rzecz w obliczu wszechświata, lecz dla mojej malutkiej osóbki bardzo ważna [...], najdroższy, a prawdę mówiąc, jedyny cel mego życia” dzieliła się pisarka wrażeniami w liście do L. Méyeta (z 1 X 1879. O-2 9). Trzeba dodać, że w Wilnie, które jeszcze niedawno słynęło z żywego ruchu umysłowego, w czasach popowstaniowych istniała tylko jedna księgarnia z polskimi książkami, przeważnie dewocyjno-religijnymi - F. Zawadzkiego; nie wychodziło żadne polskie pismo; języka polskiego nie wolno było używać w rozmowach na ulicy, zakazano robić szyldy w tym języku; uniwersytet wileński pozostawał zamknięty. Dlatego też swoją inicjatywę Orzeszkowa traktowała jako doniosłą patriotyczną misję. Zob. więcej na ten temat S. Rosiak, Księgarnia „E. Orzeszkowa i S-ka” w Wilnie. Wilno 1938. - A. Ro m a now s ki, Pozytywizm na Litwie. Polskie życie kulturalne na ziemiach litewsko-białorusko-inflanckich $w$ latach 1864-1904. Kraków 2003, s. 115-147.

6 Prospekt wydawniczy księgarni Orzeszkowej, wydrukowany w Warszawie w olbrzymim, 100-tysięcznym nakładzie (pisarka chciała pozyskać prenumeratorów w stolicy i rozreklamować firmę), ukazał się w maju 1880, kolportować go miały wytypowane warszawskie periodyki; niektóre, jak „Bluszcz”, „Kurier Warszawski”, odmówiły. Tekst tego prospektu nie jest dziś znany, zachował się tylko otwierający go wiersz W. Chełmińskiego (cyt. za: Rosiak, op. cit., s. 52-53), którego dwie końcowe zwrotki brzmią:
„Lecz ten jest człowiekiem, któremu przyświeca
Idea wolności, jak gwiazda bez cienia,
Kto wiarę i miłość wśród braci roznieca,
Kto słowa w czyn zmienia.
Kto $\mathrm{w}$ walce $\mathrm{z}$ wrogami hart ducha $z$ dobywa,
Do walki tej idzie w miłości puklerzu,
"Dziśs" kocha przez "jutro" i z "wczoraj" nie zrywa,
O świętym pomnąc przymierzu”.

W „Kalendarzu dla Izraelitów” Goldszmita prospekt nie ukazał się, pojawiła się natomiast reklama ksiegarni i jej wydawnictw.

7 Cyrkularz - urzędowe zawiadomienie o założeniu jakiejś instytucji, firmy, itp., tu zapewne: zapowiedź „Kalendarza dla Izraelitów”. Prospekt kalendarza wymieniony w kolejnym liście (prospekty omawiały zazwyczaj program publikacji, reklamowały ją, informowały o zawartości) nie dochował się.

8 Prawdopodobnie chodzi o krótką wizytę Orzeszkowej w Warszawie w dniach od 18 do 29 VII tego roku w drodze powrotnej z Drezna, Wiednia, Pragi, Krakowa. Pisarka zatrzymała się, jak zwykle, w Hotelu Saskim, prawie cały czas chorowała. W trakcie bytności w Dreźnie nie zastała Kraszewskiego, a chciała go poznać, w Krakowie spotkała się z Bałuckim (W 457).

$9 \quad$ Leopold M é y e t (1850-1912), adwokat i literat warszawski, długoletni, wierny i oddany przyjaciel Orzeszkowej, jej „pełnomocnik literacki” (dzieje przyjaźni zob. w zbiorze listów do niego $\langle\mathrm{O}-2\rangle$, liczne wzmianki o niej w pozostałych tomach). Jego szkice nowelistyczne Do nieznajomej. Nowele (Wilno 1882) ukazały się w wydawnictwie Orzeszkowej, Liście. Fragmenty i szkice (Kraków 1895) autor zadedykował pisarce; fragment prozy Gasnace lato znalazł się w kalendarzu familijnym Goldszmita „Warszawianin”. 


\section{Szanowna Pani!}

Doprawdy! że nie wiem, jak właściwie zacząc pisanie niniejsze, bo do dziś dnia, pomimo upływu tygodnia prawie od czasu otrzymania Jej listu, nie ochłonałem dostatecznie $z$ wrażenia tymże listem wywołanego. Boć mamżeż opisywać Szan[ownej] Pani cała geneze powstania „Kalendarza Izraelskiego”, myśl rzuconą przez p. Cohna ${ }^{1}$, wspólnie przez nas podjęta, a dalsze wykonanie której włożono na moje barki, pomiędzy innymi cała część administracyjno-techniczną, prowadzenie formalności, zebranie materiałów, jeszcze mozolne ślęczenie nad częścią informacyjną, dostarczanie odpowiedniej ilości artykułów, itd., itp. Mamże Szan[owna] Panią wtajemniczać w szczegóły postępowania p. Cohna oraz w wybryki jego humoru? Mamże mówić, że ponieważ umowę z drukarnią Ungra ${ }^{2}$, gdzie „Kalendarz Izraelski” się drukuje, ja zawierałem, i że ponieważ takaż sama umowa z papiernią „Jeziorna” ${ }^{3}$ [na] mnie ciąży itd., że przeto mniemany współwydawca „Kalendarza” wszystko to na moje zwalił barki, sam, pomimo zobowiązań względem mnie i czytającego ogółu zaciagniętych - usunąwszy się zupełnie na bok. Ależ, na miły Bóg! jakie mi do tego przysługuje prawo? Na jakiej zasadzie mogę mieć śmiałość obarczania Szan[ownej] Pani osobistymi sprawami? Czynienia Szan[ownej] Pani, że tak rzekę, powiernica czynów i postępków a wydarzeń czyichś?

Nie! wolę to pozostawić chyba już p. Méyetowi, którego, że w obecnej porze w Warszawie nie ma - żal mi szczery i serdeczny; on jeden tylko albowiem wpływem swoim, jaki u Szan[ownej] Pani posiada, mógłby mnie wydźwignąc $z$ tego nieszczęścia, w jakie, niestety! mimo woli wpadłem. - Dość chyba będzie, gdy powiem krótko: że to p. Cohn wycofał się z wydawnictwa „Kalendarza” po dobrowolnym porozumieniu się ze mną, jedynie i wyłącznie z powodu choroby żony swojej, bawiącej na kuracji i letnim mieszkaniu w Mrozach, skutkiem czego, zmuszony przesiadywać u niej prawie cztery dni w tygodniu oraz narażony na nadzwyczajne ekspensa - nie jest żadną miarą w stanie - jak mówił - ani materialnych ponosić kosztów, ani umysłowa jakąkolwiek zająć się pracą ${ }^{4}$.

Ustanowione tedy między nami zostało, żeby o tym fakcie współpracownikom ani inserentom ${ }^{5}$ nie donosić, a dopiero po pojawieniu sie „Kalendarza”, w przedmowie do tegoż, przedmiot ów kilką omówić słowy. Aby zaś w części chociaż wynagrodzić mi zawód mimowolnie - jak mi się to zdawało - mi przezeń sprawiony, p. Cohn przedstawił w „Kalendarzu” oba, podówczas już całkowicie złożone, artykuły Szanownych Pań. - Gdy zaś artykuł Pani Kościałkowskiej uznałem za zbyt obszerny, odniosłem się, idąc za radą ży czliwa tegoż p. Cohna, do autorki jeszcze przed dniem $20 \mathrm{bm}$., prosząc o przysłanie mi innej, w miejsce już nawet złożonej, jakiejś nowelki i przesyłając nawet, jak to sobie miałem zaleconym, ukłon od p. Cohna. Jakież jednak było przerażenie moje, gdym z listu Szan[ownej] Pani wyczytał o piśmie następnie przez p. Cohna wysłanym wprost do Szan[ownej] Pani i o żądaniu tamże wyrażonym? ${ }^{6}$ Gdybyś mnie Szan[owna] Pani bliżej cokolwiek znała, to uwierzyłabyś, sądzę, słowom moim, żem do dziś dnia oka nie zmrużył?, żem nie mógł ponadto jeszcze, skutkiem tego, przyjść do siebie. No, ale dajmy temu spokój!

Przy niniejszym przesyłam Szan[ownej] Pani artykuł Jej, już całkowicie od 
miesiąca przeszło złożony, którego cenzor „Kalendarza” całkowi cie ni e pr zep u ścił, jak mówił, z powodu tendencji w nim zawartej. Ile miałem zachodu $z$ tym, zanim zdołałem uzyskać zmianę cenzora, zanim wystosowawszy rekurs do Komitetu Cenzury udało mi się p. Kiticyna zamienić na p. Worszewa ${ }^{7}$, o tym jeden tylko Bóg a... i p. Cohn wie dokładnie. Udało mi się nareszcie uzyskać aprobatę cenzury, $z$ bardzo małymi ograniczeniami, na zmianę całości wcale nie wpływającymi. Obecnie w zupełności uznaniu i sumieniu Pani Szanownej pozostawiam: zrobić ze swą praca, respective zaś i ze mną, co się tylko Pani podoba. Pozwolisz mi Pani drukować prace już złożoną i w drukarni dawno opłaconą - zgoda; nie pozwolisz Pani - poddaję się również Jej woli. Tyle tylko powiem, że w powołaniu się na artykuł Pani i ja podobny i w tym samym duchu napisałem ${ }^{8}$, w czym $z$ dzielna przyszedł mi również pomoca szczerze mi życzliwy p. Kazimierz Kaszewski ${ }^{9}$. Pozbawienie wydawnictwa mego artykułu Pani, pozbawi mię zarazem dwóch prac powyższych, co mię w prawdziwą rozpacz wprawia, tym bardziej że wszyscy moi znajomi (L. Meyét, B. Prus, Kl. Junosza, Ant. Pilecki itp. ${ }^{10}$ ) bawią za granica i nie mam kompletnie kim wyręczyć się w napisaniu czegoś innego. A tu umowa $z$ p. Ungrem dobiega kresu, cierpię więc i $z$ tej strony, bo jemu potrzeba czcionek, a mój „Kalendarz” się nie odbija.

Zresztą, streszczę rzecz cała. Skutkiem pewnych familijnych okoliczności rzuciłem świątynię Temidy i w pół roku przybyłem do Warszawy, gdzie wyłącznie pracy dziennikarskiej się oddałem. Prawdopodobnie stanę na czele organu izraelskiego, którego dziś jestem stałym współpracownikiem ${ }^{11}$. Oto przyczyna - dlaczego „przysługę" p. Cohna tak dotkliwie czuję, dotkliwiej daleko aniżeli stratę materialna paruset rubli, jaką na wydawnictwie „Kalendarza” poniosę. Czytelnicy albowiem „Izraelity” posądzić mię mogą o lekceważenie ich. A co potem będzie ze mną? W każdym razie $\mathrm{z}$ p. Cohnem porozumiewać się więcej nie myślę i nie mogę, a całą decyzję co do wyjątkowej sprawy niniejszej zdaję na ręce Szan[ownej] Pani i jej decyzji z niecierpliwością oczekiwać będę, wraz z łaskawym oznaczeniem cyfry honorarium za cenny trud danego artykuliku.

I w końcu jeszcze jedna prośba.

Racz mi, Pani, łaskawie pozwolić przedrukować w moim „Kalendarzu” obrazek Bałuckiego Stara Mośkowa z jego Typów i obrazków krakowskich ${ }^{12}$. Nie lubię przedruków w ogóle, tym więcej, że jest to rzecz znana już czytającemu ogółowi. Że jednak na miejsce artykułu panny Kościałkowskiej nic dotychczas nie mam, a tłumaczeń dawać nie chcę, przeto obrazek ten, jako mający wiele bardzo wdzięku i powabu dla swej prostoty i naturalności, dałbym $z$ chęcią. Proszę również o łaskawe zakomunikowanie mi cyfry należności, jaka za to ode mnie przypadać będzie. Gdyby nad spodziewanie moje, rzecz ta nie od Pani, a tylko od autora zależała, to uprzejmie prosiłbym o wskazanie mi jego adresu oraz pare wierszy rekomendacyjnych od siebie.

Odbitkę z ogłoszenia Szan[ownej] Pani mam zaszczyt przesłać przy niniejszym dla korekty, proszę o zwrot wraz z artykułem Szan[ownej] Pani (przez cenzora nazwanym $\mathrm{Na}$ czasie), w każdym albowiem razie odbitka ta do cenzury oddaną być musi na powrót.

W końcu pozwolę się Szan[ownej] Pani zapytać: Czy mogę przesłać Szan[ownej] Pani egzemplarz powieści mojej, poświęconej J. I. Kraszewskiemu pt. Dramat rodzinny ${ }^{13}$, która co tylko opuściła prasę ( $z$ drukarni Ungra), a której jeden egzemplarz 
wysyłam jednocześnie $z$ niniejszym p. Méyetowi [---] do Ostendy. Zdanie o pracy mojej usłyszane od Szan[ownej] Pani większe daleko znaczenie miałoby u mnie aniżeli wszystkie recenzje drukowane powołanych, ale nie zawsze... wybranych krytyków.

Proszę, racz Szanowna Pani przyjać ode mnie zapewnienie wysokiego szacunku i

poważania, $z$ jakim pozostać mam honor sługa

JGoldszmit

Dzielna 6

Za zbyt obszerna korespondencję moją oraz za niedbalstwo w pisaniu - racz mi Szan[owna] Pani wybaczyć. Wina to usposobienia mojego, w jakim się obecnie właśnie znajduję.

Gold.

\section{Warszawa}

28 sierpnia $1881 \mathrm{r}$.

1 Znajomość Cohna z Orzeszkową dokumentują listy z różnych lat, zachowało się ich 11 (AEO, sygn. 800). Projektodawca „Kalendarza” był jedną z tych osób, do których autorka Meira Ezofowicza zwracała się z prośbą o wskazówki bibliograficzne do dziejów żydowskich i judaizmu (listy pisarki nie zachowały się, odpowiedzi A. J. C o hn a - w listach z 4 I i 6 VI 1878). Kontakt nawiazał się już wcześniej, prawdopodobnie z okazji publikowania w „Izraelicie” nowelki Daj kwiatek! (1877, nry 23-28. Przedruk w: E. O r z e s z k o w a, Z różnych sfer. Nowele i obrazki. T. 3. Warszawa 1886), w której autorka uwieczniła m.in. znaną postać Grodna, rabina Nochima, opiekuna ubogich. Sześć listów z 1881 r. omawia sprawę „Kalendarza dla Izraelitów”. List z 1883 r. zawiera także prośbę o polemikę z wypowiedzią T. T. J eża w „Prawdzie” (nr 43), szkalującą Żydów. Dwa z 1905 r. donoszą o powrocie Cohna z Petersburga, o stracie żony (chorowała od dawna, przykuta do łóżka) i córki, o wznowieniu pracy w „Izraelicie”, prosi się też w nich o współpracę. W „Izraelicie” Cohn omawiał powieści: Eli Makower (1876, nry 15-17), Meir Ezofowicz (1879, nry 2-4), był pierwszym recenzentem rozprawy $O$ Żydach $i$ kwestii żydowskiej (1882, nry 20-21), za wzór właściwego wypowiadania się o sprawach żydowskich często stawiał dzieła pisarki. Z okazji 40-lecia jej twórczości opublikował szkic Elizie Orzeszkowej, autorce „Meira Ezofowicza”, hołd (jw., 1906, nr 7).

2 Drukarnia Józefa Ung r a (1817-1874), prowadzona, po jego śmierci, przez adoptowanego syna, Gracjana (Jeżyń skiego) Ungra (1853-1911), istniała od r. 1842, należała do jednej z największych w Warszawie, w 1874 r. zatrudniała ponad 100 pracowników, miała sześć maszyn drukarskich z motorem parowym, co na owe czasy stanowiło rzadkość. Unger był też wydawca i księgarzem; edytował i drukował „Dziennik Warszawski”, „Tygodnik Ilustrowany”, „Wędrowca”, także książki: J. I. Kraszewskiego, H. Rzewuskiego, J. Łuszczewskiej. „Józefa Ungra Kalendarz Warszawski”, wychodzący w latach 1846-1917, nie miał sobie równych wśród publikacji tego typu, nazywano go nieraz „królem kalendarzy” (w r. 1855 jego nakład wynosił 30 tys. egz.).

3 Papiernia w Jeziornie należała do najstarszych zakładów papierniczych w Polsce. W roku 1775 baron Jan Kurtz zwrócił się do króla Stanisława Augusta Poniatowskiego z propozycją założenia w Jeziornie papierni. W powstałej wtedy Królewskiej Fabryce Papieru czerpano papier, służący m.in. do spisania Konstytucji 3 maja.

4 A. J. Cohn w liście z 5 VIII 1881 do E. Orzeszkowej napisał: „Wskutek okoliczności ode mnie niezależnych, wedle wszelkiego prawdopodobieństwa zmuszonym będę, dawszy inicjatywę wydawnictwu, od dalszego w nim udziału odstapić i zebrane materiały przekazać do dalszego użytku panu Jakubowi Goldszmit. 〈Dlatego〉 zapytuję Szanowna Panią, czy by zgodziła się na wydrukowanie artykułu w "Kalendarzu", gdyby ten ostatni miał wyjść nie pod moją redakcją i bez mojego udziału?"

5 Inserent - ogłoszeniodawca.

6 Chodzi zapewne o następujący passus z kolejnego listu A. J. C o h n a do E. Orzeszkowej (z 9 VIII): 
„Udało mi się przezwyciężyć przeszkody i uzyskać możność wydania "Kalendarza" w roku przyszłym [tj. 1882]. P. Zygmunt Miłkowski w liście z Paryża datowanym także na ten czas przyrzekł mi współpracownictwo. Pozwalam sobie niniejszym dodatkową jeszcze do Szan[ownej] Pani zanieść prośbę. Chodzi mi mianowicie o to, abym "Kalendarz" już pod m oj ą redakcją wyjść mający - mógł ozdobić pracami prawdziwie wyborowymi, do jakich na pierwszym miejscu zaliczam "Wstęp" przez Szan[owna] Panią napisany. Nieskończenie też byłbym wdzięczny Szan[ownej] Pani, gdyby raczyła zgodzić się, aby "Wstęp" ten do roku przyszłego w moim zachowaniu i z przeznaczeniem do "Kalendarza" przyszłorocznego mógł pozostać".

7 Aleksadr Trofinowicz Kiti c y n i Piotr Iwanowicz W or s ze w - cenzorzy Warszawskiego Komitetu Cenzury.

8 Chodzi zapewne o tekst Do czytelników autorstwa Jakuba G old s z m i ta, otwierający część literacko-publicystyczną „Kalendarza”, nawiązujący do szkicu Orzeszkowej.

9 Fragment niejasny. Kazimierz Ka s zews ki (1825-1910), krytyk niechętny pozytywizmowi, był wówczas (1879-1890) m.in. współredaktorem „Kłosów”. Czyżby jego pomoc miała dotyczyć umieszczenia w tym piśmie także wspomnianego w liście tekstu z „Kalendarza”? K. Estreicher (Bibliografia polska XIX stulecia. T. 9. Wyd. 2, nowe. Kraków 1970) nie wymienia jednak „Kłosów” jako miejsca druku prac Goldszmita. Wcześniej w „Kłosach” (1867, nr 127) brat Jakuba, Józef zamieścił szkic biograficzny o Achillesie Fouldzie (wydanie osobne w serii „Wizerunki Wsławionych Żydów XIX Wieku”〈1869〉); spotkał się on z krytyką autora „Gazety Polskiej” (1869, nr 228) za utrwalanie żydowskiego separatyzmu: „Czyżby uważał ich [tj. Żydów] za sławniejszych przez to, że Żydami byli?”. Wywiązała się polemika - odpowiedział S. H. P elty n, redaktor naczelny „Izraelity” (1869, nr 2), że nie o separatyzm chodzi, ale o „nader lojalną chęć rehabilitowania tego przez tyle wieków odrzucanego plemienia”. W roku 1867 w „Izraelicie” w ramach podobnie pomyślanej serii ukazały się trzy życiorysy pióra Jakuba: o muzyku Michale Guzikowie, filantropie Eliaszu Perlu, dobroczyńcy Szymelu Kaftanie. Mimo zapowiedzi obaj bracia nie opracowali więcej „wizerunków wsławionych Żydów”. Napisali natomiast: Józef - życiorys Łukasza Koncewicza, nauczyciela lubelskiego gimnazjum, zmarłego w czasie epidemii; Jakub - wspomnienie o ks. Ignacym Misińskim, nieżyjącym już prefekcie lubelskich szkół.

Kaszewski nieraz wypowiadał się krytycznie o twórczości Orzeszkowej - m.in. w „Kłosach” (tu zarzucał autorce rozpraw $O$ wpływie nauki na rozwój miłosierdzia oraz Patriotyzm i kosmopolityzm pominięcie chrześcijaństwa w dziejach dobroczynności), w „Bluszczu”, „Bibliotece Warszawskiej”, „Echu Muzycznym, Teatralnym i Artystycznym”. Pisarka żaliła się (w liście do J. Karłowicza. W 550), że jako redaktor „Tygodnika Romansów i Powieści” wykreślał Kaszewski z drukowanej tam powieści Pierwotni (1883) fragmenty antyklerykalne i wolteriańskie. Przywróciła je Orzeszkowa później w wydaniu książkowym.

W roku 1878 na łamach „Kłosów” ukazał się pierwodruk Meira Ezofowicza. Powieści z życia Żydów. Wydawca pisma był wówczas Salomon Lewental, autorka zwróciła się do niego po odmowie redaktora „Tygodnika Ilustrowanego”, Ludwika Jenikego („nie miał śmiałości”, W 282). W roku 1881 ukazał się w „Kłosach” Szkic biograficzny W. Zy ndra m-Kościałkow s ki ej o Orzeszkowej, w r. 1882 - recenzja rozprawy O Żydach i kwestii żydowskiej, napisana przez A. Kra u s hara.

10 B. Prus był kolegą szkolnym Jakuba. Wraz z A. Świętochowskim i J. Ochorowiczem uczęszczali obaj do 8-klasowego gimnazjum (później przemianowanego na liceum) w Lublinie. „Przywódca bandy młodych zawadiaków” - o A. Głowackim napisał J. O c h or o w i c z (Przed trzydziestu laty. „Kurier Codzienny” 1897, nr 1); o Jakubie zaś - „stanowczy idealista, swoje ćwiczenia szkolne drukował w kalendarzach” (cyt. za: M. F alkow s ka, Rodowód Janusza Korczaka. „Biuletyn Żydowskiego Instytutu Historycznego" 1997, s. 42).

Klemens Szaniawski (pseud. Junosza), autor powieści i opowiadań obyczajowych, w tym - o tematyce żydowskiej (np. Łaciarz. Kartka z życia ludzkiej niedoli 〈1884〉, Froim. Szkic z natury 〈1889〉), wbrew opinii o nim jako o antysemicie przedstawiał w nich biedotę żydowską na ogół z sympatią, apelował też o solidarność Polaków i Żydów wobec zaborcy (np. Cud na kirkucie, 1888). Tłumaczył z języka jidysz, m.in. dwie najlepsze powieści Sz. J. Abra mowicza (M. M. Sfori$\mathrm{m}$ a) Szkapa (1873) i Don Kiszot żydowski (1878). Z Goldszmitem znał się zapewne jeszcze z Lublina, z czasów współpracy z „Kalendarzem Lubelskim”, później zaś miał z nim kontakt, gdy sekretarzował redakcji „Echa”.

Antoni Pile cki (1853-1921), poeta, krytyk literacki, adwokat, od r. 1873 - stały współpracow- 
nik „Przeglądu Tygodniowego” (w rubryce Przeglad literatury powieściowej śledził uważnie przejawy literatury polsko-żydowskiej, m.in. recenzował Powiastki z życia żydowskiego 〈odbitka Z „Izraelity” 1880)). W roku 1875 został redaktorem „Opiekuna Domowego”, obecny również autorsko w „Gazecie Sądowej Warszawskiej” i prasie polonijnej („Dziennik Chicagowski”, „Zgoda”), wypowiadał się pochwalnie o Elim Makowerze (w „Opiekunie Domowym” i „Przeglądzie Tygodniowym”), drobne utwory zamieszczał w pismach: „Bluszcz”, „Kłosy”, „Izraelita” (np. Żydzi w kraju naszym dawniej i $w$ chwili obecnej, 1881), „Kurier Codzienny”, „Kurier Warszawski”, „Nowiny” itd., a także w kalendarzach Goldszmita. Prowadził ożywioną działalność odczytową, m.in. na cele dobroczynne.

11 Mowa o piśmie „Izraelita” (1866-1915), organie warszawskich integracjonistów (kolejne podtytuły: „Pismo tygodniowe poświęcone interesom judaizmu” 〈1866-1868〉; „Organ poświęcony sprawom religii i oświaty” 〈1869-1880〉; „Pismo tygodniowe” 〈1881-1905〉; „Tygodnik społeczny, literacki i naukowy" 〈1906〉 itd.). Wydawcą i redaktorem był Samuel Peltyn (do śmierci w r. 1896). Nakład w r. 1870 wynosił 700 egz., w r. 1896 - 1280 egz., połowa rozchodziła się w Warszawie, połowa na prowincji. Cena prenumeraty kwartalnej: w Warszawie 1 rubel, na prowincji - 1,23. Jakub Goldszmit zamieszczał tu korespondencje i artykuły (w latach 1866-1881). Gościł na łamach pisma również jego brat, Józef, tu też ukazał się jego nekrolog (1896). Po latach J. K o r c z a k opublikuje w tygodniku (1904) 12-odcinkowy cykl „kolonijny” pt. „Michałówka”. Kolonia dla dzieci żydowskich. (Z notatek dozorcy) (nry 41-45, 47-53), autor w spisie treści podany jako H. G old s z m it. Zob. monografię tygodnika: Z. Kołodziej s ka, „Izraelita” (1866-1915). Znaczenie kulturowe i literackie czasopisma. Kraków 2014.

W roku 1899 (nry 27-28) tygodnik opublikował wyjątki z 4 listów E. Or ze s zk owej do S. Peltyna (z lat 1870-1871) wkomponowane w artykuł $Z$ powodu ostatniego wydania dzieł Orzeszkowej, którego autorem był H. Le w. Tu znalazła się m.in. odpowiedź autorki Meira Ezofowicza na złożoną jej propozycję prenumeraty: „Z wielką pilnością zapoznawać się będę z pismem wydawanym przez Pana dla jego współwyznawców i ośmielam się mieć nadzieję, że przysłużę mu się w czymkolwiek, jeśli Pan nie odrzuci pióra chrześcijanki, która wszakże jednakim uczuciem ogarnia wszystkich swych braci, jakimkolwiek byłoby ich wyznanie” (list z 12 IV 1871. AEO, sygn. 333). W następnym liście (z 10 IX 1871) donosiła o swoich wrażeniach z lektury: „Pismo to czytam zawsze z wielką przyjemnością i korzyścią, a piękne i rozumne rzeczy, jakie w nim znajduję, obudzają we mnie dla Wydawcy i kierownika Jego najgłębszy szacunek" (AEO, sygn. 333). Peltyn po latach przesłał Orzeszkowej książkę swego autorstwa (opublikowaną pod pseudonimem Ju daita) Projekt reformy $w$ judaizmie ze szczególnym uwzględnieniem jego strony etycznej (1885) i opatrzył przesyłkę takimi oto słowy: „Jako wysoka myślicielka i koryfeuszka wiedzy judaistycznej mam nadzieję, że książkę tę uzna Szan[owna] Pani za godną przeczytania i może nie bezpożytecznie wydana”” (list z 16 X 1885. AEO, sygn. 399). W „Izraelicie” trwała też dyskusja, czy utwory Orzeszkowej zaliczają się do literatury polsko-żydowskiej. Maria Blu mberg (nie udało się ustalić jej związku z Malwiną Blumberg, wnuczką nadrabina Warszawy Ber Meiselsa i niemiecką tłumaczką Orzeszkowej) twierdziła, że tak (Powieści z życia żydowskiego 〈1896, nr 10〉), A. J. C o h n (Nasz dorobek literacki 〈1901, nr 10〉) przeczył (na podstawie kryterium tożsamości autora; później jednak zmienił zdanie (Sprawa literacka 〈1906, nr 12〉), pozostając przy kryterium tematu (,jej piękne utwory nie znalazły naśladowców").

W roku 1901 (nr 18) zamieszczono, przedrukowany z petersburskiego „Kraju”, tekst hołdu złożonego autorce Meira Ezofowicza przez deputację Żydów wileńskich z okazji jubileuszu; w 1907 r. (nr 1) przedstawiono syntezę stanowiska pisarki w kwestii żydowskiej (Sprzed 25 laty). Po śmierci Orzeszkowej poświęcono jej całe wydanie „Izraelity” (1910, nr 6) z piękną fotografią na froncie. Wśród materiałów wyróżniało się ujęte w ramkę, wydrukowane dużymi czcionkami zdanie (cytat?): „Mój kamień mogilny mieć będzie napis: braterstwo i zgoda”. W synagodze na Tłomackiem odbyło się uroczyste nabożeństwo żałobne, wieniec z szarfą: „Krzewicielce zgody i braterstwa”, w imieniu „Izraelity” złożył Józef Wasercug. O żydowskich związkach Orzeszkowej nie zapomniano i później - zob. Orzeszkowa jako bojowniczka praw żydowskich. „Nasz Przegląd” 1929, nr 287 (z dziennikiem tym, organem izraelskiej inteligencji warszawskiej, współpracował Korczak).

12 M. Bałucki, Typy i obrazki krakowskie. Wilno 1881. Drukiem J. Blumowicza. 11 pozycja Wydawnictwa E. Orzeszkowa i S-ka. Wymieniony utwór Jakub Goldszmit przedrukował w „Kalendarzu”, z niewielkimi zmianami, nadając mu tytuł Typowa Żydówka. (Obrazek z życia), po wyrażeniu 
zgody przez obie zainteresowane osoby (zob. list 3). Oprócz Starej Mośkowej tomik zawierał jeszcze 15 innych „obrazków” o różnorodnej tematyce obyczajowej.

13 Dramat rodzinny. Kartka z dziejów partykularza. Opowiedział Jakub Gold s z mit. Warszawa 1881. Książkę tłoczyła drukarnia Ungra. Tomik zaopatrzony w dedykację: „Czcigodnemu J. I. Kraszewskiemu, Nestorowi naszych powieściopisarzy utwór niniejszy w dowód szacunku poświęca Autor", oraz w wierszyk:

Mistrzu! Dusza twa, uczuciem wielka,

Wita słowami żywymi

Ród, w którym uczuć choćby kropelka

Barwami świeci jasnymi.

I jam do ciebie wyciagał rękę

Po rad życzliwych jałmużnę,

I moje serce (przyjm tę podziękę!)

Wiele, o mistrzu, ci dłużne.

Tyś nieraz wlał w nie słodka pocieche,

Dziś znów pod twoja prowadzę strzechę

To moje dziecię kochane.

Błaga myśl, $z$ ducha mego poczęta

Błogosławieństwa twej dłoni,

Trwożna, jak owe drobne ptaszęta,

Orzeł niech skrzydłem osłoni.

Warszawa, 25 sierpnia 1881.

\section{Szanowna Pani!}

Spieszę najuprzejmiej podziękować Szan[ownej] Pani tak za udzielone mi pozwolenie druku cennego artykułu Pani, jak również i za łaskawie mi nadesłany list rekomendacyjny do p. Bałuckiego, z którego skorzystać nie omieszkam. Artykuł Szan[ownej] Pani składa sie już powtórnie, a to z tej przyczyny, że nie mając dość długo (w moim przynajmniej mniemaniu) odpowiedzi i będąc naciskanym przez drukarnię Ungra wciąż, która, mówiąc nawiasem, nie ma znów tak zbyt wiele petitu, którym cały „Kalendarz” mój się składa - kazałem go rozebrać. Obecnie jednak jest już na nowo złożony i dziś poszle go się powtórnie do cenzury.

Kwestię honorarium za cenna pracę Pani, jeżeli Szan[owna] Pani pozwoli, załatwię z p. Méyetem, którego przyjazdu w przyszłym już tygodniu z Ostendy, gdzie obecnie bawi, się spodziewamy, i który, o ile mi wiadomo, posiada zaufanie Szan[ownej] Pani ${ }^{1}$.

Żądane egzemplarze „Kalendarza Izraelskiego” wnet po wyjściu jego $\mathrm{z}$ druku z prawdziwą przyjemnością przesłać Szan[ownej] Pani nie omieszkam.

Raz jeszcze uprzejmie dziękuję Szan[ownej] Pani za łaskawe spełnienie mej prośby, łączę zapewnienie wysokiego mego szacunku i poważania i pozostaję wdzięcznym sługą

JGoldszmit

Leszno nr 65

Warszawa

16/9 $1881 \mathrm{r}$. 
Méyet często odbierał w Warszawie honoraria należne Orzeszkowej. Przeciętne wynagrodzenie za wiersz wynosiło w jej przypadku około 20 groszy. 100 rubli za Pannę Antoninę wypłacono Méyetowi w redakcji „Biesiady Literackiej” w 1882 r. (W 611). Znacznie większe honoraria miał otrzymywać w tym czasie H. Sienkiewicz, o czym nieraz donosiła prasa ówczesna, a Méyet - Orzeszkowej.

Abstract

\section{JAKUB GOLDSZMIT'S LETTERS TO ELIZA ORZESZKOWA PART 1}

Edited by BOŻENA WOJNOWSKA Institute of Literary Research of the Polish Academy of Sciences, Warsaw

The article contains letters, commentaries, and an introduction. In the first part the reader is given three Jakub Goldszmit's letters dated 1881, while the author's remaining correspondence (11 pieces produced between 1881-1909) is expected to be published in one of the forthcoming issues of "Pamiettnik Literacki" ("Literary Memoir"). The introduction focuses on Orzeszkowa's attitude to the Jewish cases, namely equality of Jews, and mutual relationship of Poles and Jews. Orzeszkowa's important statement about the matters in question is her own text Wstepne słowo (Introduction) contained in Goldszmit's publication "Kalendarz dla Izraelitów" ("Calendar for the Israelites") (1881). Jakub Goldszmit's and Józef's - his brother (Janusz Korczak's father) - activities on the one hand allow for sketching here a picture of acculturation process in the Goldszmit family. On the other hand, they give an example for building a parallel between the advocates of integrationalism and Orzeszkowa's attitude to the Polish (and also Jewish) case. As long as in political commentary papers she at times approached (though multidirectionally) the positivist stance which considered the Jewish situation instrumentally through the prism of Polish interests, in her literary pieces she succeeded in going beyond the limits which the then polonocentrism imposed on its contemporaries. Being in his literary pieces far from subjecting the aims of Jewish regeneration to the needs of Polish modernisation, Orzeszkowa managed to consider the unassisted role of integrative movement and appreciated the internal values of Jewish life. She also discerned the analogy between Polish historical fortune and the historical position of people which brought the idea of monotheism and its moral implications to culture. 